\title{
CHECKBOOK JOURNALISM, FREE SPEECH, AND FAIR TRIALS
}

\author{
SCOTT C. PUGH†
}

\section{INTRODUCTION}

On June 14, 1994, the Los Angeles coroner's office revealed that Nicole Brown Simpson, O.J. Simpson's former wife, and Ronald Goldman died as a result of "sharp force injuries," possibly knifeinflicted stab wounds. ${ }^{1}$ Not long after O.J. Simpson's arrest in connection with the murders, ${ }^{2}$ an employee and a part-owner of a Los Angeles cutlery store, Jose Camacho and Allen Wattenberg, alleged that Simpson had recently visited their store and had purchased a fifteen-inch knife. ${ }^{3}$ They also claimed that Simpson had requested that they sharpen the knife before turning it over to him. ${ }^{4}$

Although Camacho and Wattenberg testified at Simpson's preliminary hearing, they had previously shared their information with the public by selling their stories to the National Enquirer. ${ }^{5}$ Although tabloid media publications often pay for stories, Camacho and Wattenberg received an uncommon $\$ 12,500$ in exchange for their story. ${ }^{6}$ After criminal proceedings against Simpson began, his defense counsel moved to dismiss Camacho, claiming that his acceptance of the money made him untrustworthy. ${ }^{7}$ When that motion was denied, Simpson's defense team responded by assailing Camacho's credibility through vigorous questioning about the transactions with the tabloid. ${ }^{8}$

† B.A. 1992, Brigham Young University; J.D. Candidate 1996, University of Pennsylvania Law School. This Comment owes a lot to the thoughtful suggestions of Hilary Siegel and to the patience and support of Jo Anne.

1 Brian McGrory, Simpson Seen as Prime Suspect, Boston Globe, June 15, 1994, at $1,22$.

${ }^{2}$ See David Ferrell \& Eric Malnic, LAPD Criticized for Leniency in Handling Case, L.A. TIMES, June 18, 1994, at A1.

${ }^{3}$ See Henry Weinstein, Free-Spending Tabloid Media Causing Judicial Concerns, L.A. TIMES, July 2, 1994, at A1, A2.

4 See B. Drummond Ayres, Jr., Store Clerk Tells Court Simpson Bought 15-Inch Knife Weeks Before the Killings, N.Y. TiMES, July 1, 1994, at A20.

${ }^{5}$ See Weinstein, supra note 3 , at A1, A2.

${ }^{6}$ See id. at A1.

7 See World News Saturday: Simpson Case Media-Paid Witnesses' Credibility (ABC television broadcast, July 2, 1994).

${ }^{8}$ For instance, Simpson's attorney asked: “'You were like a businessman, and you 
Shortly after Camacho and Wattenberg made their deals with the National Enquirer, a witness named Jill Shively surfaced, also claiming to possess information that inculpated Simpson. She alleged that she saw Simpson speeding through the streets near the murder scene "like a madman"9 in his now infamous white Bronco on the night the victims were killed. ${ }^{10}$ Like Camacho and Wattenberg, Shively first opted to tell her story to tabloid media organizations and accepted payments for it $-\$ 5000$ from the television tabloid Hard Copy and $\$ 2600$ from the Star, a supermarket tabloid. ${ }^{11}$ When the prosecution learned Shively had taken money for her story, it dropped her from its witness list. ${ }^{12}$

The actions of Camacho, Wattenberg, and Shively ${ }^{13}$ represent a new species of an old problem: extrajudicial statements by trial participants. Paying individuals for information, known as "checkbook journalism, ${ }^{n 14}$ is a relatively new practice which entails its own peculiar package of risks to fair trials. ${ }^{15}$ By taking money from a tabloid media outlet in exchange for information about which she will testify in court, a witness may subvert a trial's integrity and a defendant's right to a fair trial.

The actions of Camacho, Wattenberg, and Shively probably represent the most recent and most conspicuous examples of checkbook journalism's foray into criminal proceedings. The Simpson case, however, is certainly not the first time checkbook journalism has played a part in a criminal prosecution or investigation. Other prominent examples include the William Kennedy Smith trial, ${ }^{16}$

wanted to sell your story to the highest bidder, didn't you?' Robin Clark, Tabloids Are Paying, but at a Cost: Journalism by Checkbook Is a Big Problem in High-Profile Cases, PHILA. INQUIRER, July 3, 1994, at C1, C8 (quoting Robert Shapiro, one of Simpson's attorneys).

${ }^{9} I d$.

${ }^{10}$ See Weinstein, supra note 3, at A2.

11 See id.

${ }^{12}$ See Clark, supra note 8, at C8; Weinstein, supra note 3, at A2.

${ }^{13}$ Simpson's friend Al Cowlings may also be added to the list of witnesses seeking to profit by selling information about the case. On February 7, 1995, Cowlings announced that he will write a book detailing his long-standing friendship with Simpson. Cowlings also promised that the book will discuss the infamous freeway chase preceding Simpson's arrest. See Debbie Howlett, Simpson Pal Cowlings to Write $B o o k$, USA TODAY, Feb. 8, 1995, at 1A.

14 The mainstream media tends to use this term pejoratively. This Comment does not use the term in any pejorative sense, but only as a shorthand way of denominating the practice of paying individuals for information.

${ }^{15}$ See infra part II.A (examining three ways in which checkbook journalism may imperil a defendant's right to a fair trial).

${ }^{16}$ During the course of Smith's prosecution on rape charges, three other women 
the Pamela Smart trial, ${ }^{17}$ the Jim Bakker trial, ${ }^{18}$ the Amy Fisher trial, ${ }^{19}$ and the Michael Jackson investigation. ${ }^{20}$

Out-of-court statements by criminal trial participants can mar a trial's integrity and thus undermine a defendant's Sixth Amendment right to a fair trial. ${ }^{21}$ They can similarly undercut public faith in the

came forward to assert that Smith had exhibited similar behavior toward them. Although the women sold this information to different media outlets, only one of them agreed to testify against Smith in court. Smith's attorney forced her to admit that she had received $\$ 40,000$ from $A$ Current Affair in exchange for her story and used this evidence to attack her motives and credibility. See Weinstein, supra note 3, at A2; WDH-TV Nezus: Tuming up the Heat (CBS affiliate, WDH-TV, television broadcast, Feb. 6, 1992).

17 This trial was a macabre case in which the defendant convinced her 15-year-old lover to murder her 24-year-old husband in the foyer of their apartment building. Key witnesses were paid for information they possessed about the case. See Jerry Miller, Smart Murder Case Attracts Attention from Hollywood, UNION LEADER (Manchester, N.H.), Oct. 8, 1990, at 9.

${ }^{18}$ In a paid interview with former Bakker mistress Jessica Hahn, Playboy broke the story that led to Bakker's eventual downfall from his ministry and to his conviction on fraud charges. See Art Harris \& Michael Isikoff, Jessica Hahn, on the Defensive, WASH. POST, Sept. 30, 1987, at C1.

${ }^{19}$ In this case, Amy Fisher, a 16-year-old girl, went to the home of her lover, Joey Buttafuoco, and shot his wife, Mary Jo Buttafuoco, in her face after the love affair had gone sour. The tabloid media paid for a great deal of information during the course of Fisher's trial. For instance, a Long Island man produced a videotape which contained scenes of him and Fisher in a sexual encounter. A Current Affair bought the video. When Fisher was released on bail, a former boyfriend secretly recorded a conversation in which Fisher seriously damaged her credibility as a witness. A Current Affair also bought this tape, which resulted in Fisher's lawyers advising her not to take the stand in her defense and in law enforcement authorities deciding not to pursue an investigation of Joey Buttafuoco. A neighbor of the Buttafuocos secretly recorded a conversation she had with Mary Jo shortly after the shooting, fetching $\$ 16,000$ from Hard Copy for the tape. The biggest profit-takers, however, were the Buttafuocos themselves. A television tabloid paid them $\$ 500,000$ for exclusive interview rights, and Tri-Star Pictures closed a deal purchasing the rights to a TV movie that could net the Buttafuocos as much as $\$ 1$ million. See Craig Gordon \& Sylvia Adcock, Amy $\mathcal{E}^{\circ}$ Joey: Crime Pays in Big Way, NewSDAY (N.Y.), Nov. 22, 1993, at 6.

${ }^{20}$ While the investigation concerning alleged molestation of juveniles was pending, Blanca Francia, one of Jackson's former maids, accepted money from Hard Copy in exchange for her story. See William Hamilton, The Muck-a-Mucks of Tabloid Journalism, WASH. Post, Dec. 16, 1993, at C1, C13; Lawyers Talk to Maid Who Said Jackson Was Nude with Boys, BOSTON GLOBE, Dec. 16, 1993, at 5. Francia told the tabloid "that she saw Jackson bathing in the nude with at least two young boys." Id. at 5 . The National Enquirer purchased the report of the caseworker who first interviewed Jackson's accuser. See Clark, supra note 8, at C8. According to Jackson's lawyer, one reason that the civil case was settled out of court and that no charges were brought by the state was that the stories sold by the witnesses to the tab-loids were inconsistent with, and more sensational than, the accounts those witnesses had previously given in sworn depositions. See Weinstein, supra note 3, at A2.

${ }^{21}$ See infra part I.A (discussing the accused's constitutional right to a fair trial). 
the justice system and contribute to the unreliability of verdicts. To guard against these risks, trial judges have employed a variety of devices, including extensive voir dire of jurors, ${ }^{22}$ postponement of trials, ${ }^{23}$ change of venue, ${ }^{24}$ change of venire, ${ }^{25}$ jury sequestration, ${ }^{26}$ special jury instructions, ${ }^{27}$ and imposition of gag orders. ${ }^{28}$

${ }^{22}$ Many of the following examples are drawn from Robert S. Stephen, Note, Prejudicial Publicity Surrounding a Criminal Trial: What a Trial Court Can Do to Ensure a Fair Trial in the Face of a "Media Circus", 26 SuFfolk U. L. REv. 1063 (1992), which also analyzes the effectiveness of these devices. On the voir dire measure, see, for example, Margoles v. United States, 407 F.2d 727, 728-32 (7th Cir.) (employing voir dire), cert. denied, 396 U.S. 833 (1969); People v. Manson, 132 Cal. Rptr. 265, 315-19 (Ct. App. 1976) (same), cert. denied, 430 U.S. 986 (1977); Khaalis v. United States, 408 A.2d 313, 335 (D.C. 1979) (same), cert. denied, 44 U.S. 1092 (1980); State v. Hale, 172 A.2d 631, 634 (Me. 1961) (same); see also Robert M. Takasugi, Jury Selection in a High Profile Case: United States v. DeLorean, 40"AM. U. L. REv. 837, 840 (1991) (summarizing Judge Takasugi's account of the devices he used-including voir dire-to safeguard John DeLorean's Sixth Amendment rights during his prosecution on federal drug charges).

${ }^{23}$ A postponement is also referred to as an "adjournment" or "continuance." See BLACK's LAW DictionARY 42, 321 (6th ed. 1990). For an example of a case in which this device was used to mitigate prejudicial publicity, see United States v. Dioguardi, 147 F. Supp. 421, 423 (S.D.N.Y. 1956).

${ }^{24}$ Change of venue attempts to remedy the prejudicial effects of an extrajudicial statement or other prejudicial information by removing the trial to an untainted location. A recent use of this measure which garnered a great deal of public attention was the Rodney King beating trial, in which the judge moved the trial of four L.A.P.D. officers from Los Angeles to Simi Valley. See Reynolds Holding, Trial's Location May Have Affected Verdict, S.F. CHRON., May 1, 1992, at A14; see also FED. R. CRIM. P. 21(a) ("The court upon motion of the defendant shall transfer the proceeding . . . to another district ... if the court is satisfied that there exists in the district where the prosecution is pending so great a prejudice against the defendant that the defendant cannot obtain a fair and impartial trial at any place fixed by law for holding court in that district."). The issue of venue may approach constitutional proportions in criminal cases. See Rideau v. Louisiana, 373 U.S. 723, 726 (1963) (stating that in some situations denial of a defendant's request for a change of venue amounts to a violation of defendant's constitutional rights); Irvin v. Dowd, 366 U.S. $717,719-20$ (1961) (discussing a constitutional challenge to a state statute that allows only one change of venue).

${ }^{25}$ Change of venire involves enlarging the panel of prospective jurors, calling in a new panel, or importing a panel from an area not suffused with prejudice against the defendant. See G. Michael Fenner \& James L. Koley, The Rights of the Press and the Closed Court Criminal Proceeding, 57 NEB. L. REv. 442, 497 (1978).

${ }^{26} \mathrm{~A}$ judge may sequester a jury during the course of trial proceedings, usually by isolating jurors in a hotel, to prevent them from being tampered with or exposed to publicity. Judge Lance Ito took this step in the ongoing prosecution of O.J. Simpson. See Andrea Ford \& Jim Newton, Ito Tells Jurors They Will Be Sequestered, L.A. TIMES, Jan. 10, 1995, at B1. Other high-profile cases in which juries have been sequestered include the Charles Manson case, the Rodney King beating case, and the Reginald Denny beating case. See Stephanie Simon \& Ralph Frammolino, Despite Perks, Sequestration Is a Guilded Cage, Jurors Say, L.A. TIMES, Jan. 15, 1995, at A1.

${ }^{27}$ A judge may "issue special jury instructions that emphasize the presumption of 
In September, 1994, the California state legislature, in response to the conduct of witnesses in the Simpson case, ${ }^{29}$ addressed the problem of tabloid-paid witnesses in criminal cases by enacting legislation prohibiting the sale of any "information obtained as a result of witnessing [an] event or occurrence" that might pertain to a criminal prosecution. ${ }^{30}$ California Assembly Speaker Willie

innocence and the need to disregard public sentiment." Terri A. Belanger, Note, Symbolic Expression in the Courtroom: The Right to a Fair Trail Versus Freedom of Speech, 62 GEO. WASH. L. REV. 318, 353 (1994); see also Close-It Enters. v. Weinberger, 407 N.Y.S.2d 587, 588 (App. Div. 1978) (stating that jury instructions can cure the effects of potential prejudice).

${ }^{28}$ Gag orders raise First Amendment concerns, and many of them have been invalidated by appellate courts on that basis. See, e.g., Journal Publishing Co. v. Mechem, 801 F.2d 1233, 1236-37 (10th Cir. 1986) (invalidating trial court's order limiting press contact with former jurors as impermissibly overbroad in violation of the First Amendment); Levine v. United States Dist. Court, 764 F.2d 590, 599 (9th Cir. 1985) (invalidating the trial court's order barring attorneys from making statements related to the case to the media as impermissibly overbroad in violation of the First Amendment), cert. denied, 476 U.S. 1158 (1986); Rodgers v. United States Steel Corp., 536 F.2d 1001, 1007-08 (3d Cir. 1976) (holding that a protective order prohibiting counsel from disclosing information obtained via discovery was an impermissible prior restraint on the exercise of First Amendment freedoms); CBS, Inc. v. Young, 522 F.2d 234, 240-41 (6th Cir. 1975) (invalidating a gag order which prevented parties from discussing the case with the media because it did not overcome the presumption against constitutional validity of prior restraints upon First Amendment freedoms); Chicago Council of Lawyers v. Bauer, 522 F.2d 242, 249 (7th Cir. 1975) (invalidating, as unconstitutionally overbroad, a district court rule and disciplinary rule of the American Bar Association that prohibited attorneys from making out-of-court statements about pending or imminent litigation, if such statements might reasonably "interfere with a fair trial or otherwise prejudice the due administration of justice"), cert. denied, 427 U.S. 912 (1976).

Some gag orders, however, have been sustained on appeal. See, e.g., In re Dow Jones \& Co., 842 F.2d 603, 611-12 (2d Cir.) (finding that only a gag order could "stop the grand jury leaks and the publicity prejudicial to defendants' rights"), cert. denied, 488 U.S. 946 (1988); Radio \& Television News Ass'n v. United States Dist. Court, 781 F.2d 1443, 1444 (9th Cir. 1986) (holding "that restraints on statements of trial participants ... do not infringe freedom of press under the first amendment"). For commentaries on the varying standards courts have used to review gag orders, see Mark R. Stabile, Note, Free Press-Fair Trial: Can They Be Reconciled in a Highly Publicized Criminal Case?, 79 GEo. L.J. 337, $349-54$ (1990); Michael E. Swartz, Note, Trial Participant Speech Restrictions: Gagging First Amendment Rights, 90 CoLUM. L. REv. 1411, 1414-15 (1990); René L. Todd, Note, A Prior Restraint by Any Other Name: The Judicial Response to Media Challenges of Gag Orders Directed at Trial Participants, 88 MICH. L. REV. 1171, 1176-81 (1990).

${ }^{29}$ See Governor Signs Bills Barring Witnesses from Selling Stories, Reuters, Sept. 26, 1994, at 1 [hereinafter Governor Signs Bills], available in LEXIS, News Library, Wires File.

${ }^{30}$ CAL. PENAL Code $\S 132.5$ (b) (West Supp. 1995). The statute states in relevant part: 
Brown, the bill's principal author, repeatedly stressed that the state's checkbook journalism law does not prevent witnesses from giving information to any media outlet they choose, but only from receiving payment for doing so. ${ }^{31}$ The state legislature justified the measure on Sixth Amendment grounds, claiming that it was necessary to ensure a fair trial for criminal defendants. ${ }^{32}$

This Comment analyzes California's statutory effort to accommodate the competing First and Sixth Amendment interests. Part I explores the parameters and underlying rationales of both the First and Sixth Amendments and the potential points of conflict between them. Part II begins by considering ways in which the statute might serve Sixth Amendment interests and, then, shows how the statute's attempt to serve these interests places a burden on free speech rights. This Part explains why the California legislative

\begin{abstract}
A person who is a witness to an event or occurrence that he or she knows is a crime or who has personal knowledge of facts that he or she knows or reasonably should know may require that person to be called as a witness in a criminal prosecution shall not accept or receive, directly or indirectly, any money or its equivalent in consideration for providing information obtained as a result of witnessing the event or occurrence or having personal knowledge of the facts.
\end{abstract}

$I d$. Violations of this statute are punishable by fines of up to three times the amount the witness received for her story and by imprisonment of up to six months. See id. \$ 132.5(e).

California also prohibits jurors from receiving money in exchange for any information about the trial. See id. § 1122. This Comment, however, deals only with those provisions which restrict the ability of witnesses, not jurors, to receive payment for information.

${ }^{31}$ See Bouncing Checkbook Journalism, HoLLywOOD REP., July 27, 1994, at 7 ("I am not barring them from saying it; I'm barring them from getting paid for it." (quoting California Assembly Speaker Willie Brown)); Jerry Gillam, Brown Says Courts Would Uphold Bill on Paid Interviews, L.A. TIMES, July 27, 1994, at A3 ("They [witnesses] can still talk to the press, but they can't make a deal." (quoting Brown)); see also CAL. PENAL CODE $\$ 132.5$ (a) (indicating that the legislature finds that disclosure of such information for valuable consideration contravenes important state interests and that the statute "is not intended to prevent any person from disseminating any information or opinion").

${ }^{32}$ See Willie L. Brown, Jr., Money Taints Trial Process: Witnesses Who Sell Their Stories Can Compromise Trial, USA TODAY, Sept. 30, 1994, at 10A (relying on the Sixth Amendment to justify the measure); Brown Discusses Proposal to Outlaw Checkbook Journalism (CNN television broadcast, July 27, 1994) (same). The State also appealed to its interest in assuring the reliability of verdicts and in shoring up public confidence in the judicial system. See CAL. PENAL CODE $\$ 132.5$ (a) (declaring that the practice of checkbook journalism in the context of criminal proceedings "threatens to erode the reliability of verdicts" and "creates an appearance of injustice that is destructive of public confidence"). These justifications are derivatives of the central Sixth Amendment justification. 
effort does not achieve the Supreme Court's avowed aim of resolving conflicts between the First and Sixth Amendments "without essentially abrogating one right or the other." ${ }^{33}$ Part II also proposes two alternate solutions for achieving the statute's goals while maintaining an acceptable balance between the rights in the First and Sixth Amendments. Finally, Part III concludes that these alternatives achieve a solution that is more respectful of traditional First Amendment policy considerations than the current statutory solution promulgated by the California legislature.

\section{Two Conflicting Constitutional Guarantees}

One of the principal guarantees of the Sixth Amendment is the right to trial by an impartial jury. This Part begins by explaining the meaning that the Supreme Court has assigned to that concept and then details the methods and feasibility of showing jury prejudice. The discussion next considers the First Amendment right to free speech and elucidates two common policy justifications for this right. It also explores the relevance to First Amendment jurisprudence of distinguishing content-neutral from content-based restrictions on speech. Finally, this Part concludes by surveying ways in which the rights in the First and Sixth Amendments can conflict with one another, focusing on how the Court has attempted to accommodate such conflicts.

\section{A. The Sixth Amendment Right to a Fair Trial}

The Sixth Amendment guarantees every criminal defendant the right to a public trial by an impartial jury. ${ }^{34}$ Courts and commentators commonly refer to this as the right to a "fair trial." The impaneling of an impartial jury is necessary but not sufficient to assure that a defendant's fair trial right is respected. ${ }^{36}$ The state

ss Nebraska Press Ass'n v. Stuart, 427 U.S. 539, 612 (1976).

${ }^{34}$ U.S. CONST. amend. VI ("In all criminal prosecutions, the accused shall enjoy the right to a speedy and public trial, by an impartial jury of the state and district wherein the crime shall have been committed.").

${ }^{35}$ See, e.g., Green v. Bock Laundry Mach. Co., 490 U.S. 504, 510 (1989) ("The Sixth Amendment to the Constitution guarantees a criminal defendant certain fair trial rights . ... .); Alfredo Garcia, Clash of the Titans: The Difficult Reconciliation of a Fair Trial and a Free Press in Modern American Sociely, CHAMPION, July 1994, at 4, 5-6 (" $[\mathrm{F}]$ airness is the preeminent value advanced by the Sixth Amendment's safeguard of a fair trial by an impartial jury.").

${ }^{36}$ See Rosales-Lopez v. United States, 451 U.S. 182, 189 (1981) (stating that the obligation to provide a fair trial "lies in the first instance with the trial judge"); 
must also ensure that the right is maintained throughout the course of trial proceedings. ${ }^{37}$ The central value served by the Sixth Amendment is fairness. All of the protections guaranteed by the Sixth Amendment, such as an impartial jury, ${ }^{38}$ the right of confrontation, ${ }^{39}$ and the right to counsel, ${ }^{40}$ share the property of promoting fairness in adjudication.

The text of the Sixth Amendment does not explain what constitutes juror impartiality. ${ }^{41}$ A certain tension pervades the Supreme Court's pronouncements on the Sixth Amendment right to a fair trial. The Court has characterized it as "the most fundamental of all freedoms" ${ }^{\$ 2}$ and as a right "essential to the preservation and enjoyment of all other rights. ${ }^{\text {"43 }}$ The Court has even asserted that the fair trial right must be maintained "at all costs. ${ }^{n 4}$ Endorsements of this kind might lead one to conclude that the Court would allow the fair trial right to trump other constitutional

Ristaino v. Ross, 424 U.S. 589, 595 (1976) (declaring that states have an "obligation to the defendant to impanel an impartial jury").

${ }^{37}$ The government must ensure that no juror is subjected to information that will make her biased at any time before rendering a verdict. See Hirschkop v. Snead, 594 F.2d 356, 365-66 (4th Cir. 1979) ("[A] properly drawn rule restricting lawyer's comments about pending criminal prosecutions can be justified by the need to protect the right to a fair jury trial."); Stephen, supra note 22, at 1082 ("[C]ourt[s] must maintain impartiality by continuously and carefully monitoring the trial proceedings and any outside activity that may prejudice the jurors.").

${ }^{38}$ See Irvin v. Dowd, 366 U.S. 717, 721-22 (1961) (noting that a trial cannot be fair if the jury is not impartial). For further discussion of the values behind the guarantee of trial by jury, see infra notes 156-59.

${ }^{39}$ See Coy v. Iowa, 487 U.S. 1012, 1017 (1988) ("There is something deep in human nature that regards face-to-face confrontation between an accused and an accuser as 'essential to a fair trial in a criminal prosecution."' (quoting Pointer v. Texas, 380 U.S. 400, 404 (1965))).

${ }^{40}$ See Strickland v. Washington, 466 U.S. 688, 684 (1984) (noting the guarantee of effective assistance of counsel exists "in order to protect the fundamental right to a fair trial"). See generally ALFREDO GARCIA, THE SIXTH AMENDMENT IN MODERN AMERICAN JURISPRUDENCE at ix (1992) (stating that a fair trial is "the core ideal" of the Sixth Amendment); LuCAS A. POWE, JR., THE Fourth Estate AND THE CONSTITUTION 279 (1991) ("Some parts of the Bill of Rights, such as the 'fair trial' provisions, promote fairness ...."). Fairness is not, however, the policy or value traditionally served by the First Amendment, and it may work in opposition to the policies or values animating the First Amendment. Id. at 278-79.

${ }^{41}$ See U.S. CoNST. amend. VI.

42 Estes v. Texas, 381 U.S. 532, 540 (1965).

${ }^{43}$ Nebraska Press Ass'n v. Stuart, 427 U.S. 539, 586 (1976); see also Chicago Council of Lawyers v. Bauer, 522 F.2d 242, 248 (7th Cir. 1975) ("WW]hen irreconcilable conflicts arise, the right to a fair trial ... must take precedence over the right to make comments about pending litigation . . . if such comments are apt to seriously threaten the integrity of the judicial process."), cert. denied, 427 U.S. 912 (1976).

${ }^{44}$ Estes, 381 U.S. at 540. 
rights to the extent they are in conflict, and that the Court would tolerate only minimal juror partiality.

In fact, the Court's Sixth Amendment jurisprudence does not bear out either of these suppositions. The Court has affirmatively indicated that no hierarchy exists among the rights enumerated in the first ten amendments. ${ }^{45}$ Hence, notwithstanding the language in some of the Court's opinions, the right to a fair trial cannot simply trump other potentially conflicting constitutional guarantees. ${ }^{46}$

Furthermore, the Court has consistently relaxed the permissible amount of prejudicial information to which a juror may be exposed, as well as the permissible firmness with which she may hold a preconceived opinion about the case or the defendant. The Court has never insisted that a jury have no knowledge of or opinion about the defendant or her alleged crime. ${ }^{47} \mathrm{~A}$ juror, therefore, can

${ }^{15}$ See Nebraska Press Ass'n, 427 U.S. at 561 ("The authors of the Bill of Rights did not undertake to assign priorities as between First and Sixth Amendment rights, ranking one as superior to the other. . . [ [I]t is not for us to rewrite the Constitution by undertaking what they declined to do.").

${ }^{16}$ See id. The Supreme Court has never accepted Justice Burger's solution of a simple hierarchical approach in which First Amendment rights always yield to Sixth Amendment rights. For Burger's views, see Press-Enter. Co. v. Superior Court, 464 U.S. 501, 508 (1984) (" [Although] no right ranks higher than the right of the accused to a fair trial ...., the primacy of the accused's right is difficult to separate from the right of everyone in the community to attend the voir dire which promotes fairness."); Richmond Newspapers, Inc. v. Virginia, 448 U.S. 555, 564 (1980) (referring to a defendant's right to a fair trial as "superior" to the right of the press and the public to attend a trial); Bridges v. California, 314 U.S. 252, 260 (1941) (noting the difficult but often unavoidable judicial task of prioritizing constitutional rights). For an example of an appellate court apparently accepting Burger's approach, see In re Dow Jones \& Co., 842 F.2d 603, 609 (2d Cir.) ("When the exercise of free press rights actually tramples upon Sixth Amendment rights, the former must nonetheless yield to the latter."), cert. denied, 488 U.S. 946 (1988).

Likewise, the Court has never taken the position that First Amendment rights are inviolate and always trump Sixth Amendment rights. See Shepherd v. Florida, 341 U.S. 50, 52-53 (1951) (noting that freedoms guaranteed by the First Amendment must sometimes be restrained in order to protect the right to a fair trail); Pennekamp v. Florida, 328 U.S. 331, 366 (1946) (Frankfurter, J., concurring) ("In securing freedom of speech, the Constitution hardly meant to create the right to influence judges or juries. That is no more freedom of speech than stuffing a ballot box is an exercise of the right to vote.").

${ }^{47}$ As far back as the celebrated treason trial of Aaron Burr, Chief Justice Marshall rejected the argument put forth by Burr that the Sixth Amendment entitled him to a panel of jurors who were "perfectly indifferent and free from prejudice." United States v. Burr, 25 F. Cas. 49, 49 (C.C.D. Va. 1807) (No. 14,962g). In 1878, the Court reiterated its view that such a standard would be unrealistic and unworkable. See Reynolds v. United States, 98 U.S. 145, 156 (1878).

The notion that a jury can be impartial only if it is totally ignorant of the 
be simultaneously impartial and opinionated.

The Supreme Court offered further guidance as to what constitutes disqualifying bias in the case of Irvin v. Dowd..$^{48}$ In Irvin, the Court reiterated its view that mere familiarity with "the facts and issues" involved in a case does not by itself amount to partiality. ${ }^{49}$ Rather, a juror is impartial for constitutional purposes if she is able to "lay aside [her] impression or opinion" and "render a verdict based on the evidence presented in court. ${ }^{n 0}$ The defendant has the burden of proving that any particular juror does not meet the standard by showing actual bias. ${ }^{51}$ One commentator has described this burden as "tremendous" because "it is up to the accused to identify the bias, demonstrate its intensity, and convince the trial judge that the jurors' 'impressions' are not light but are firmly etched within the recesses of the mind. ${ }^{n 2}$

However, the Irvin Court left open a small window for defendants seeking to prove juror bias by creating a second category of bias which also violates the Sixth Amendment: presumptive bias. Where a "pattern of deep and bitter prejudice' [against the defendant] . . . throughout the community" is revealed, a presump-

defendant's background and the crime she is alleged to have committed drew biting criticism from Mark Twain: "We have a criminal jury system which is superior to any other in the world; and its efficiency is only marred by the difficulty of finding twelve men every day who don't know anything and can't read." MARK TWAIN, SKETCHES NEW AND OLd 235 (New York, Harper \& Bros. 1899) (1875). Twain also stated,

[W] hen a gentleman of high social standing, intelligence, and probity swears that testimony given under solemn oath will outweigh, with him, street talk and newspaper reports based upon mere hearsay, he is worth a hundred jurymen who will swear to their own ignorance and stupidity. ... Why could not the jury law be so altered as to give men of brains and honesty an equal chance with fools and miscreants?

2 MARK TWAIN, Roughing It 56-57 (Author's Nat'l ed., Harper \& Bros. 1913) (1871). For an argument that informed citizens generally make the best jurors, see Newton N. Minow \& Fred H. Cate, Who Is an Impartial Juror in an Age of Mass Media?, 40 AM. U. L. REV. 631, 656-60 (1991).

48366 U.S. 717 (1961).

${ }^{49}$ See id. at 723 .

${ }^{50} I d$.

${ }^{51}$ See id. ("The affirmance of the issue is upon the challenger. Unless he shows the actual existence of such an opinion in the mind of the juror as will raise the presumption of partiality, the juror need not be set aside."); see also Murphy v. Florida, 421 U.S. 794, 800 (1975) (noting that "it remains open to the defendant to demonstrate" actual bias on the part of a juror (emphasis added)).

${ }^{52}$ Garcia, supra note 35, at 9 (commenting on the Reynolds case upon which the Irvin Court relied for its conclusion that a juror is sufficiently impartial if she can set aside her impressions or opinions and base her judgment on the evidence presented in court). 
tion of partiality may properly arise. ${ }^{53}$ Even when jurors profess an ability to set aside their preconceptions regarding a defendant's guilt, it may, depending on the circumstances surrounding the case, be presumed that the jurors' claims of impartiality are untrustworthy and, therefore, that the defendant cannot or did not receive a fair trial. ${ }^{54}$

Lower courts applying the doctrines articulated in Irvin have interpreted them as affording the defendant two avenues for proving that her jury was or will be impartial. One possibility is that she can rely on voir dire testimony and other evidence to prove that a juror was actually biased against her. Alternatively, she can argue that the circumstances surrounding her trial are so prejudicial that a presumption of juror partiality is warranted. ${ }^{55}$

Two subsequent Supreme Court cases, Murphy v. Florida ${ }^{56}$ and Patton $v$. Yount, ${ }^{57}$ cast serious doubt on the continued viability of the presumptive bias prong. In both cases, jurors and their communities were exposed to extremely prejudicial, inadmissible information about the defendants. ${ }^{58}$ Both defendants were convicted and subsequently challenged their convictions on presumptive bias grounds. ${ }^{59}$ Distinguishing earlier cases, the Court refused to infer a presumption of juror bias in either case. ${ }^{60}$ The

${ }^{53}$ Irvin, 366 U.S. at 727 (citations omitted).

${ }^{54}$ See id. at 728.

${ }^{55}$ See generally Minow \& Cate, supra note 47 , at $642-43$ (collecting cases in which courts have discussed actual and presumptive bias and applied the two-part Irvin test).

${ }^{56} 421$ U.S. 794 (1975).

57467 U.S. 1025 (1984).

${ }^{58}$ In Murphy, jurors had knowledge of the defendant's prior convictions for murder and robbery, including his notorious heist of the Star of India sapphire from a museum in New York. See Murphy, 421 U.S at 795-97. They were also exposed to extensive news accounts about the crimes for which he was then on trial. See id. Patton involved the retrial of a defendant on the charges of rape and murder of an 18-year-old high school student. See Patton, 467 U.S. at 1026-28. The defendant's initial conviction was overturned after it was determined that the confession used against him in the original trial was illegally obtained. See id. Four years later, media coverage of the defendant's second trial resulted in wide circulation of the following facts: that the defendant had previously been convicted of murder, that he had confessed, and that he had asserted a temporary insanity defense during the first trial. See id. As one pair of commentators put it, "it would be difficult to imagine a case in which prejudice could more easily be proven or presumed." Minow \& Cate, supra note 47 , at 645 .

${ }^{39}$ See Patton, 467 U.S. at 1028-29; Murphy, 421 U.S. at 797.

${ }^{60}$ See Patton, 467 U.S. at 1040 (finding that the trial was fair); Murphy, 421 U.S. at 803 (same). In both cases, the Court noted that the time between the prejudicial publicity and the actual trials diminished any effects of the publicity. See Patton, 467 U.S. at 1032; Murphy, 421 U.S. at 802. 
Court did not explicitly repudiate presumptive bias as a means of proving a violation of the right to a fair trial, but its refusal to find presumptive bias in either case led commentators to question whether that prong of the test for juror impartiality is still good law. ${ }^{61}$ At the very least, these decisions force one to conclude that the "standard for presuming prejudice may be impossible to satisfy." ${ }^{\text {T2 }}$ Therefore, the difficulty of proving presumed or actual juror partiality, like other Sixth Amendment limitations recognized by the Court, ${ }^{63}$ makes a particular defendant's task of proving an infringement of her right to a fair trial quite formidable. ${ }^{64}$

\section{B. The First Amendment Right to Free Speech}

The following section lays the groundwork for Parts II and III, which explain the legal and policy failures of the California statute, by briefly summarizing First Amendment legal doctrine and policy theory. After describing the two major theoretical justifications ${ }^{65}$

${ }^{61}$ See, e.g., Minow \& Cate, supra note 47, at 643 (construing these cases as eliminating the presumptive bias prong and requiring actual bias before a fair trial violation will be found).

${ }^{62} I d$. at 646 (footnote omitted); see also Garcia, supra note 35, at 10 (describing the task of showing presumptive bias as a "herculean exploit").

${ }^{63}$ To prove a violation of the Sixth Amendment right to counsel, for example, a defendant must demonstrate that her attorney was highly inadequate and responsible for committing serious errors. See Strickland v. Washington, 466 U.S. 668, 686 (1984) (holding that the attorney's incompetence must rise to the level at which "the trial cannot be relied on as having produced a just result"). Similarly, at a joint trial, a codefendant's confession that clearly implicates another defendant, as long as it does so only inferentially, is not a violation of the Confrontation Clause. See Richardson v. Marsh, 481 U.S. 200, 206-11 (1987) (holding that only a confession that facially incriminates another defendant violates the Confrontation Clause); see also U.S. CoNST. amend. VI (providing the right to confront witnesses).

${ }^{64}$ This survey is not a criticism of the way the Court has interpreted the Sixth Amendment, but rather is simply meant to lay the groundwork for an evaluation of whether the harms against which California has purportedly acted to protect are the kinds of harms which might justify an abridgement of free expression. For an argument that the Court's Sixth Amendment jurisprudence is insufficiently solicitous of defendants' rights, see generally Garcia, supra note 35.

${ }^{65}$ Other notable justifications for freedom of expression include the individual self-fulfillment rationale, the checking rationale, and the safety-valve rationale. See THOMAS I. EMERSON, THE SYSTEM OF FREEDOM OF EXPRESSION 7 (1970) (discussing the safety-valve rationale); Vincent Blasi, The Checking Value in First Amendment Theory, 1977 AM. B. FOUND. RES. J. 521 (discussing the checking rationale); Martin H. Redish, The Value of Free Speech, 130 U. PA. L. REV. 591 (1982) (discussing the safety-valve rationale); Thomas Scanlon, $A$ Theory of Freedom of Expression, 1 PHIL. \& PUB. AFF. 204 (1972) (discussing the self-fulfillment rationale). This Comment focuses on the marketplace of ideas and self-governance theories of the First Amendment, both because they are historically dominant (in the decisions of the Supreme Court as well 
for freedom of expression, this discussion turns to an explanation of the important legal doctrine governing free speech jurisprudence.

\section{The Marketplace of Ideas Rationale}

The oldest and perhaps most popular justification for freedom of speech is that truth is best attained through free trade in ideas. ${ }^{66}$ The foundation of this rationale is the notion that speech achieves truth and that the fewer restrictions that are placed upon speech, the more likely it is to discover the truth. ${ }^{67}$ On the Supreme Court, Holmes and Brandeis were the most ardent and eloquent defenders of this view. As Holmes wrote in his famous Abrams dissent,

when men have realized that time has upset many fighting faiths, they may come to believe ... that the ultimate good desired is better reached by free trade in ideas-that the best test of truth is the power of the thought to get itself accepted in the competition of the market. ${ }^{68}$

In developing its First Amendment jurisprudence, the Supreme Court has consistently relied upon the logic of the marketplace of ideas. ${ }^{69}$

as in the academic literature) and because they provide the most insight into the issues discussed. The one exception is a brief note on the congruence between the arguments presented here and the "checking rationale" of the First Amendment. See infra note 194.

${ }^{66}$ Milton first gave voice to this view in Areopagitica. See JOHN MILTON, AREOPAGTICA 51-52 (John W. Hales ed,, London, Oxford University Press 3d ed. 1882) (1644) ("Let [Truth] and Falsehood grapple; who ever knew Truth put to the wors [sic] in a free and open encounter?"). Later, the marketplace of ideas rationale would serve as the heart of John Stuart Mill's classic work, On Liberty. For further discussion and criticism of this justification for freedom of speech, see, for example, $C$. EDWIN BAKER, HUMAN LIBERTY AND FREEDOM OF SPEECH 6-24 (1989) (discussing some frailties of the theory); FREDERICK SCHAUER, FREE SPEECH: A PHILOSOPHICAL INQUIRY 15-34 (1982) (discussing the value of truth); Kent Greenawalt, Free Speech Justifications, 89 CoLUM. L. REV 119, 130-41 (1989) (discussing the merits of truth discovery).

${ }^{67}$ See Stanley Ingber, The Marketplace of Ideas: A Legitimizing Myth, 1984 DUKE L.J. $1,3,5$ (explaining that this theory of free expression is patterned after a laissez-faire economic theory which asserts that "desirable economic conditions are best promoted by a free market systems," rather than government regulation, and stating that "[the marketplace of ideas] theory assumes that a process of robust debate, if uninhibited by governmental interference, will lead to the discovery of truth").

${ }_{68}^{6}$ Abrams v. United States, 250 U.S. 616, 630 (1919) (Holmes, J., dissenting); see also Whitney v. California, 274 U.S. 357, 372, 375 (1927) (Brandeis, J., concurring) (arguing that the Framers "believed that freedom to think as you will and to speak as you think are means indispensable to the discovery and spread of political truth"); Gitlow v. New York, 268 U.S. 652, 673 (1925) (Holmes, J., dissenting) (citing Abrams).

${ }^{69}$ See BAKER, supra note 66, at 7-12 (reviewing numerous opinions in which 


\section{The Self-Governance Rationale}

Another leading justification for the First Amendment, developed most forcefully by Alexander Meiklejohn, is that a democratic system requires the protection of speech relating to issues of public interest or, defined broadly, political matters. ${ }^{70}$ For the people to truly govern themselves, this theory contends, they must be free to listen to arguments on all sides of any matter of public concern. ${ }^{71}$ In short, if it is the people who exercise control by way of the political process in a democracy, that is, if they are to decide which policies the nation shall pursue, and by which means, then the people must make fully informed and knowledgeable decisions. The First Amendment, by prohibiting the exclusion of any speech relevant in this regard, assures that "all facts and interests relevant to the problem shall be fully and fairly presented." 72

In the seminal case of New York Times $v$. Sullivan, ${ }^{73}$ the Supreme Court at least partially adopted the Meiklejohn interpretation of the First Amendment. Sullivan was brought by a public official of Montgomery, Alabama, who claimed to have been libeled when a group of students and clergymen published, in the New York Times, an advertisement critical of the city's treatment of civil rights

marketplace imagery dominates the Court's discussions of free speech).

${ }^{70}$ See alexander MEIKlejohn, Free SpeEch and Its Relation to SelfGOVERNMENT 1-27 (1948).

71 "[T]he vital point, as stated negatively, is that no suggestion of policy shall be denied a hearing because it is on one side of the issue rather than another." Id. at 26. There is a wealth of commentary both defending and attacking this theory of the First Amendment. See, e.g., BAKER, supra note 66, at 25-33 (comparing political speech with the marketplace of ideas theory); Lilian R. BeVier, The First Amendment and Political Speech: An Inquiry into the Substance and Limits of Principle, 30 STAN. L. REV. 299, 304-22 (1978) (finding fault with the then-prevailing political speech view); Robert H. Bork, Neutral Principles and Some First Amendment Problems, 47 IND. L.J. 1, 20-35 (1971) (agreeing in part with Meiklejohn's theory); Zechariah Chafee, Jr., Book Review, 62 HARV. L. REV. 891 (1949) (reviewing MEIKLEJOHN, supra note 70, and defending his views); SCHAUER, supra note 66, at 35-46 (explaining and distinguishing Meiklejohn's argument).

72 MEIKLEjoHN, supra note 70, at 25. Dr. Meiklejohn once explained his understanding of the First Amendment in the following way:

Public discussions of public issues, together with the spreading of information and opinion bearing on those issues, must have a freedom unabridged by our agents. Though they govern us, we, in a deeper sense, govern them. Over our governing, they have no power. Over their governing, we have sovereign power.

Alexander Meiklejohn, The First Amendment Is an Absolute, 1961 SuP. CT. REv. 245, 257.

${ }^{73} 376$ U.S. 254 (1964). 
advocates. ${ }^{74}$ The Court set aside the judgment of the Supreme Court of Alabama in favor of Mr. Sullivan and went on to establish a very tough standard for public official plaintiffs in libel actions. ${ }^{75}$ More importantly, the Court rested its holding on the notion that the basic aim of the First Amendment is to foster an "unfettered interchange of ideas for the bringing about of political and social changes." ${ }^{76}$ Justice Brennan, who authored the opinion, understood Sullivan as implicitly rejecting earlier justifications of the First Amendment, such as the "clear and present danger" test, the "redeeming social value" test, and "balancing" tests." $\mathrm{He}$ also noted that the opinion was consistent with Meiklejohn's theory of the First Amendment. ${ }^{78}$

Although Sullivan literally applies to libel cases only, Professor Harry Kalven, Jr., the most prominent First Amendment commentator of his time, predicted that its logic would "follow a dialectic progression from public official to government policy to public policy to matters in the public domain. ${ }^{\text {79 }}$ The self-governance rationale has since been applied by the Court in almost every First Amendment context, suggesting that Professor Kalven was right. ${ }^{80}$

${ }^{74}$ See id. at $256-65$.

${ }^{75}$ See id. at 283 (requiring public officials bringing libel actions to prove that false statements about them were made knowingly or with reckless disregard of the statement's truth or falsity).

${ }^{76}$ Id. at 269 (quoting Roth v. United States, 354 U.S. 476, 484 (1957)). The Court also stated that "debate on public issues should be uninhibited, robust, and wideopen, and ... it may well include vehement, caustic, and sometimes unpleasantly sharp attacks on government and public officials." Id. at 270.

${ }^{7}$ See William J. Brennan, Jr., The Supreme Court and the Meiklejohn Interpretation of the First Amendment, 79 HARV. L. REv. 1, 9, 14-15 (1965) (discussing the ramifications of this viewpoint).

${ }^{78}$ See id. at 9-10 (seeming to concur in Professor Harry Kalven, Jr.'s assessment that the opinion was in "substantial agreement" with Meiklejohn's theory). Justice Brennan's subsequent opinions and speeches leave no doubt as to the influence of the Meiklejohn interpretation of the First Amendment on his own understanding of it. See Richmond Newspapers, Inc. v. Virginia, 448 U.S 555, 587 (1980) ("[T]he First Amendment embodies more than a commitment to free expression and communicative interchange for their own sakes; it has a structural role to play in securing and fostering our republican system of self-government." (emphasis onitted) (citations omitted)); Garrison v. Louisiana, 379 U.S. 64, 74-75 (1964) ("[S]peech concerning public affairs is more than self-expression; it is the essence of self-government."); Justice William J. Brennan, Jr., Address at the Dedication of the S.I. Newhouse Center for Law and Justice in Newark, New Jersey (Oct. 17, 1979), in 32 RUTCERS L. REV. 173,176 (1979) ("[T]he First Amendment protects the structure of communications necessary for the existence of our democracy.").

${ }^{79}$ Harry Kalven, Jr., The New York Times Case: A Note on "The Central Meaning of the First Amendment", 1964 SUP. CT. REv. 191, 221.

${ }^{80}$ See LeE C. BOLlinger, IMAGes OF A Free Press 8-19 (1991) (cataloguing the 


\section{Constitutional Standards}

The Supreme Court's distinction between content-neutral and content-based speech restrictions is "the most pervasively employed doctrine in the jurisprudence of free expression." 81 The central concept of the rule against content-based speech restrictions is that the "government has no power to restrict expression because of its message, its ideas, its subject matter, or its content. ${ }^{82}$ A speech restriction that is content based is one that limits expression because of its "communicative impact." ${ }^{\text {"3 }}$

However, to say that the government may never discriminate against speech on the basis of its content is to overstate the case. The rule, rather, is that in order to do so the government must be prepared to show that the restriction is necessary to serve a compelling government interest and is narrowly tailored to serve that interest-the so-called strict scrutiny standard. ${ }^{84}$ Narrow tailoring is a concept that eludes easy definition. When applied to

application of this principle to cases in the following areas: libel, national security, public access to the press, invasion of privacy, intentional infliction of emotional distress, taxation, free press/fair trial, and the right to gather news).

${ }^{81}$ Geoffrey R. Stone, Content Regulation and the First Amendment, 25 WM. \& MARY L. REv. 189, 189 (1983).

${ }^{82}$ Police Dep't v. Mosley, 408 U.S. 92, 95 (1972); see also Texas v. Johnson, 491 U.S. 397, 414 (1989) ("If there is a bedrock principle underlying the First Amendment, it is that the government may not prohibit the expression of an idea simply because society finds the idea itself offensive or disagreeable.").

${ }^{83}$ See e.g., Turner Broadcasting Sys., Inc. v. FCC, 114 S. Ct. 2445, 2467 (1994) (explaining that the flaw in a previously invalidated statute was that it burdened expression based on "communicative impact" and was a content-based preference (discussing Buckley v. Valeo, 424 U.S. 1, 17 (1976))); United States v. Eichman, 496 U.S. 310, 317-18 (1990) (holding that the Flag Protection Act of 1989 "suppresses expression out of concern for its likely communicative impact" and thus "cannot be 'justified without reference to the content of the regulated speech" (citation omitted)); Texas v. Johnson, 491 U.S. 397, $411-12$ (1989) (stating that regulations which restrict speech because of its communicative impact are content-based and, therefore, subject to strict scrutiny); see also LAURENCE TRIBE, AMERICAN CONSTITUTIONAL LAW \$ 12-2, at 789-90 (2d ed. 1988) (summarizing government actions which restrict speech because of its "specific message or viewpoint" as abridgements "aimed at communicative impact" (emphasis omitted)); Stone, supra note 81, at 190 ("Content-based restrictions ... limit communication because of the message conveyed. Laws that prohibit seditious libel, ban the publication of confidential information, forbid the hiring of teachers who advocate the violent overthrow of government, or outlaw the display of the swastika in certain neighborhoods illustrate this type of restriction.").

${ }_{84}$ See Widmar v. Vincent, 454 U.S. 263, $269-70$ (1981) (defining strict scrutiny); Carey v. Brown, 447 U.S. 455, 461, 464-65 (1980) (same); Mosley, 408 U.S. at 101 (same). 
content-based speech restrictions, ${ }^{85}$ narrow tailoring means that there must be a very "tight fit" between the harm associated with the speech and the means employed to prevent it. ${ }^{86}$ Means that are either overinclusive or underinclusive-that proscribe either too much or too little speech-can be fatal flaws. ${ }^{87}$ A government

${ }^{85}$ The Court's scrutiny is less severe when the speech restriction is content neutral. See Ward v. Rock Against Racism, 491 U.S. 781, 798 (1989) (upholding a regulation of concert noise in Central Park and stating that "a regulation of the time, place or manner of protected speech must be narrowly tailored to serve the government's legitimate, content-neutral interests but that it need not be the least restrictive or least intrusive means of doing so"); Clark v. Community for Creative Non-Violence, 468 U.S. 288, 299 (1984) (rejecting CCNV's argument that because other "less speech-restrictive alternatives" existed, the First Amendment required the government to use them).

${ }^{86}$ Professor Tribe explains the concept this way:

The Court . . . requires an especially close nexus between ends and means.

A statute must be narrowly drawn so that a challenged act of government

is clearly an efficacious means to achieve permissible objectives of

government and is narrowly aimed at those permissible objectives so as not

unnecessarily to reach expressive conduct protected by the first amendment.

TRIBE, supra note $83, \S 12-8$, at 833 . The Court has occasionally stated that for a speech regulation to be narrowly tailored, the government must be able to show that there is no "less restrictive means" of achieving its stated interest. See infra note 177 (discussing the "least restrictive means" formulation of the strict scrutiny standard).

${ }^{87}$ Justice Blackmun defined an overinclusive statute as "one that encompasses more protected conduct than necessary to achieve its goal." Church of Lakumi Babalu Aye, Inc. v. Hialeah, 113 S. Ct. 2217, 2251 (1993) (Blackmun, J. concurring). Another author states that "overinclusiveness" in the Court's free speech cases refers to "unnecessarily restricted speech." The Supreme Court, 1991 Term-Leading Cases, 106 HARV. L. REv. 163, 286 (1992). For examples of speech restrictions that the Court has held invalid because of overinclusiveness, see, for example, Arkansas Writers' Project, Inc. v. Ragland, 481 U.S. 221, 232 (1987) (finding that a sales tax exemption granted to certain categories of magazines was overinclusive and, therefore, not narrowly tailored to serve the state's interest in fostering the growth of "fledgling" magazines because it applied to all magazines that fell within the specified categories, regardless of whether they were financially struggling or "lucrative and well-established"); infra notes 120-25 and accompanying text (discussing Simon \& Schuster, Inc. v. New York State Crime Victims Bd., 112 S. Ct. 501 (1991)).

"While surprising at first glance, the notion that a regulation of speech may be impermissibly underinclusive is firmly grounded in basic First Amendment principles." City of Ladue v. Gilleo, 114 S. Ct. 2038, 2043 (1994). An underinclusive speech restriction is one that "targets some conduct or actors for adverse treatment, yet leaves untouched conduct or actors that are indistinguishable in terms of the law's purpose." William E. Lee, The First Amendment Doctrine of Underbreadth, 71 WASH. U. L.Q. 637, 637 (1993). The rationale commonly given for the underinclusiveness doctrine is closely tied to the self-governance rationale discussed above. An underinclusive speech restriction can be used by the government to suppress ideas or information it finds objectionable, for example, by giving an advantage to one side in a public debate. See R.A.V. v. City of St. Paul, 112 S. Ct. 2538, 2547 (1992) ("St. Paul has no .... authority to license one side of a debate to fight freestyle, while 
action that suppresses speech because of its content will fail the narrow tailoring test whenever it can be shown that more speech would avert the harm connected with the suppressed speech. ${ }^{88}$

The presumption against content discrimination is a logical outgrowth of the marketplace of ideas rationale of the First Amendment. The assumption implicit in the rule that speech can only be suppressed because of its content when one cannot count on "a further exchange of ideas ${ }^{n 89}$ to avert the harm associated with the speech is that truth will ultimately win the day in the marketplace

requiring the other to follow Marquis of Queensbury Rules."); First Nat'l Bank v. Bellotti, 435 U.S. 765, 785-86 (1978) (stating that "where . . . legislature's suppression of speech suggests an attempt to give one side of a debatable public question an advantage in expressing its views to the people, the First Amendment is plainly offended" (footnote omitted)). Underinclusive restrictions on expression can also be government tools for setting the terms of public discussion. See Consolidated Edison Co. v. Public Serv. Comm'n, 447 U.S. 530, 538 (1980) (stating that government may attempt to select the "permissible subjects for public debate" through such restrictions or mischaracterizations). Underinclusive speech regulations thus tend to frustrate the ideal of democratic self-governance. See supra part I.B.2 (discussing the ideal of self-governance).

${ }^{88}$ In his concurring opinion in Whitney v. California, 274 U.S. 357 (1927), Justice Brandeis wrote: "If there be time to expose through discussion the falsehood and fallacies, to avert the evil by the processes of education, the remedy to be applied is more speech, not enforced silence." Id. at 377 (Brandeis \& Holmes, JJ., concurring). The Court has subsequently adopted Brandeis's view, requiring that the government justify content-based speech restrictions by showing that more speech would not effectively prevent the harm associated with the restricted speech. See Texas v. Johnson, 491 U.S. 397, $419-20$ (1989) (invalidating a Texas statute proscribing desecration of the U.S. flag and stating that the constitutionally prescribed means of "preserv[ing] the flag's special role" is not punishing those who mistreat it but "persuad[ing] them that they are wrong"); FCC v. League of Women Voters, 468 U.S. 364, 398 (1984) (holding that a provision of the Public Broadcasting Act of 1967 that forbade noncommercial broadcasters from receiving funds under the Act to "engage in editorializing" was not narrowly tailored to achieve the end of promoting balanced and fair presentations on such broadcasters, as compared to requiring them to permit more speech, including contrasting views); Brown v. Hartlage, 456 U.S. 45, 61 (1982) (explaining that a Kentucky statute requiring that a candidate for public office forfeit his election victory if, during the campaign, he erroneously announces that if elected he will serve at a reduced salary was not sustainable under the First Amendment because correction and critique by the candidate's campaign opponent would serve the state's interest without punishing expression of political ideas); Linmark Assocs. v. Township of Willingboro, 431 U.S. 85, 96-97 (1977) (holding unconstitutional an ordinance banning the posting of "For Sale" and "Sold" signs enacted to discourage "white flight" from racially integrated neighborhoods and suggesting that Willingboro could achieve its objectives through "more speech," such as "Not for Sale" signs and other publicity); see also TRIBE, supra note 83, § 12-8, at 833-34 ("Whenever the harm feared could be averted by a further exchange of ideas, governmental suppression is conclusively deemed unnecessary." (emphasis omitted)).

${ }^{89}$ TRIBE, supra note $83, \S 12-8$, at 833 . 
of ideas. ${ }^{90}$ The presumption against content discrimination also accords with the self-governance rationale of the First Amendment; the ideal of the people making the system's most important decisions, equipped with all pertinent information and having heard the relevant arguments on all sides of an issue, would be thwarted if the government could exclude ideas from public debate. ${ }^{91}$

\section{Conflict Between the First and Sixth Amendments}

The constitutional right of free speech-and specifically, the right of free press-generally harmonizes with the constitutional right to a fair trial. "Public scrutiny of a criminal trial enhances the quality and safeguards the integrity of the factfinding process, with benefits to both the defendant and to society as a whole." 92 The opportunity for the public to observe and review trial proceedings serves as a check on government abuse of power. ${ }^{93}$

The Supreme Court has also recognized, however, that occasionally the free speech and fair trial rights can work at cross-purposes. ${ }^{94}$ Sometimes the maelstrom of public interest surrounding a criminal trial ${ }^{95}$ is so intense that it becomes exceedingly difficult for the state to furnish a jury that measures up to the constitutional standard of impartiality. ${ }^{96}$ As noted earlier, the Court has rejected

${ }^{90}$ See supra part I.B.1 (discussing the marketplace of ideas justification for freedom of speech).

${ }_{91}$ See supra part I.B.2 (discussing the self-governance justification for freedom of speech).

${ }^{92}$ Globe Newspaper v. Superior Court, 457 U.S. 596, 606 (1982). "[P]ublic access to the criminal trial fosters an appearance of fairness, thereby heightening public respect for the judicial process." Id.; see also Press-Enter. Co. v. Superior Court, 464 U.S. 501,508 (1984) ("Openness thus enhances both the basic fairness of the criminal trial and the appearance of fairness so essential to public confidence in the system."). Jeremy Bentham, in his diatribes against the use of secret trials in England, was perhaps the first to point out the manner in which the rights to observe and report on criminal proceedings can shore up the right to a fair trial. See 1 JEREMY BENTHAM, RATIONALE OF JUdicial EvidenCE 524 (London, Hunt \& Clark 1827).

${ }^{93}$ See In re Oliver, 333 U.S. 257, 270 (1948) ("The knowledge that every criminal trial is subject to contemporaneous review in the forum of public opinion is an effective restraint on possible abuse of judicial power.").

94 See Times-Picayune Publishing Corp. v. Schulingkamp, 419 U.S. 1301, 1307 (1974) (recognizing that reconciling these two rights is sometimes a difficult task); Bridges v. California, 314 U.S. 252, 260 (1941) ("[F]ree speech and fair trials are two of the most cherished policies of our civilization, and it would be a trying task to choose between them.").

${ }^{95}$ These cases normally involve either high-profile defendants or particularly gruesome crimes. See Stephen, supra note 22, at 1066.

${ }^{96}$ This standard may, however, be satisfied even if jurors are aware of a 
resolving such conflicts between the First and Sixth Amendments by simply assigning priority to one right over the other. ${ }^{97}$ Rather, the Court has sought to resolve the conflict "without essentially abrogating one right or the other. ${ }^{98}$

\section{The California Statute Under Constitutional Scrutiny}

This Part begins by considering three possible aims of California's checkbook journalism statute to determine whether any one of them constitutes a compelling governmental interest. It then explains why the California statute banning checkbook journalism is a content-based restriction on free expression. Finally, this Part discusses whether this content-based restriction survives constitutional review and concludes that it does not because it is not narrowly tailored to achieve its ends. This narrow-tailoring analysis also outlines two alternate, narrowly-tailored means of accomplishing the statute's goals, which are later shown, in Part III, to conform with the policy justifications behind free speech.

\section{A. Purposes of the Califormia Statute}

The California legislature was relatively vague in spelling out just what the checkbook journalism statute was designed to accomplish. ${ }^{99}$ Legislators rarely explained which specific rights they had in mind when debating the bill, but they often indicated a concern for rights embodied in the Sixth Amendment. ${ }^{100}$ The following discussion explores three possible ways in which the statute may further Sixth Amendment interests and addresses the degree to which each is a compelling governmental interest.

defendant's criminal background and of the details of the crime with which she is charged, see Murphy v. Florida, 421 U.S. 794, 800 (1975) (rejecting the defendant's challenge on grounds of actual bias under those circumstances), and even if jurors have a "preconceived notion as to the guilt or innocence of [the] accused." Irvin v. Dowd, 366 U.S. 717, 723 (1961).

${ }^{97}$ See supra note 46 (discussing the Court's refusal to allow Sixth Amendment rights categorically to outweigh First Amendment Rights).

${ }^{98}$ Nebraska Press Ass'n v. Stuart, 427 U.S. 539, 612 (1976).

${ }^{99}$ See CAL. PENAL CODE $\$ 132.5$ (a) (declaring that the statute "is intended to preserve the right of every accused person to a fair trial, the right of the people to due process of law, and the integrity of judicial proceedings").

${ }^{100}$ See supra note 32 and accompanying text (discussing the legislature's Sixth Amendment justifications). 


\section{The Lying Witness Theory}

One possible motivation behind the enactment of the California statute may be a belief that the practice of checkbook journalism promotes exaggerated or false testimony in court. ${ }^{101} \mathrm{~A}$ witness who takes money in exchange for information may have an incentive to exaggerate, to embellish, or even to fabricate her story. Should the individual later be called as a witness at a criminal trial, she may feel compelled to stand by her earlier imperfect account for various reasons, such as a desire to maintain credibility. This basis for the statute unquestionably implicates a compelling governmental interest-namely, seeing that false testimony is not proffered in judicial proceedings. ${ }^{102}$

\section{The Incredulous Jury Theory}

A second and closely related theory is that checkbook journalism results in the loss of credible evidence because juries will consider the witness unreliable due to the financial interest the witness has in the testimony. Under this theory, the fear is not that a witness will exaggerate or lie under oath, but rather that the jury will infer that she did exaggerate or lie and, hence, will discount the value of her testimony. ${ }^{103}$ Whereas the harm to be averted under the lying witness theory is the injection of false testimony into trials, the harm under the incredulous jury theory is the rejection by skeptical jurors of true and reliable testimony.

Whether a state's interest in discouraging juror incredulity of witnesses is compelling is somewhat unclear. When viewed in the most general terms, a state probably has a compelling interest in

${ }^{101}$ See The Ethics of Checkbook Journalism (NPR radio broadcast, July 29, 1994) (airing California Assembly Speaker Brown's assertions that, when witnesses are paid, they are "sometimes motivated to lie, or to . . expand and embellish their stories"). On the day the bill was signed by the Governor of California, Brown stated, "This kind of payment for testimony jeopardizes the very integrity of the criminal justice system by encouraging false testimony." See Governor Signs Bills, supra note 29, at 1.

${ }^{102}$ See, e.g., Taylor v. Illinois, 484 U.S. 400, 417 (1988) (stating that state officials "ha[ve] a vital interest in protecting the trial process from the pollution of perjured testimony").

${ }^{103}$ This was the theory upon which Speaker Brown most often relied. See Bouncing Checkbook Journalism, supra note 31, at 1 ("Payment . . . creates doubts in the minds of jurors about the credibility of the witness."); Gillam, supra note 31, at A3 ("A witness who tells the truth, but admits to being paid for his story, may lose credibility in the eyes of the jury." (quoting Brown)); Brown Discusses Proposal to Outlaw Checkbook Journalism, supra note 32 (arguing that jurors should consider a witness's motive for testifying in deciding how much weight to accord his testimony). 
discouraging juror incredulity of witnesses based on its desire to ensure the accuracy of verdicts. Discouraging juries from unduly discounting the testimony of certain witnesses could thus be viewed as a way of promoting jury verdicts that are faithful to the evidence in given cases, something that is certainly a compelling state interest. ${ }^{104}$

When examined more closely, however, a state's interest in deterring jury incredulity of witnesses looks less compelling. ${ }^{105}$ At bottom, the state's interest under this theory is in minimizing the extent to which jurors dismiss otherwise reliable testimony because of the taint brought about by witnesses' financial dealings with the media. Essentially, this avowed purpose seeks to prevent the injection into trial of witnesses who appear lacking in credibility. As this Comment argues below, however, determining witness credibility has traditionally been one of the fundamental roles of the jury. ${ }^{106}$ Hence, the proposition that a state has a compelling interest in wresting control of witness credibility issues from the jury is at least questionable.

\section{The Prejudicial Publicity Theory}

A final theory is that the practice of checkbook journalism might induce a witness to make public information-true or fabricatedthat, but for the financial incentive, she would otherwise share only with authorities and, eventually, possibly with the jury. The fear behind this theory is that the added incentive to publicize such information could result in extensive prejudicial publicity, perhaps

104 This undertaking could, thus, be characterized as a means of advancing the truth-finding function of the courts, see United States v. Robinson, 485 U.S. 25,33 (1988) (indicating that this is the "central purpose of a criminal trial"), as a way of ensuring that verdicts are based only on evidence presented in court, see Patterson v. Colorado, 205 U.S. 454, 462 (1907) ("The theory of our system is that the conclusions to be reached in a case will be induced only be evidence and argument in open court, and not by any outside influence, whether of private talk or public print."), or as a way of enhancing public confidence in the reliability of verdicts. See In re Winship, 397 U.S. 358, 363-64 (1970) (emphasizing the strong societal interest in the reliability of verdicts).

${ }^{105}$ The core of this Comment's critique goes to the means by which the statute pursues its stated ends, but not the ends themselves. Thus, this discussion only briefly raises arguments that suggest that the statute's stated ends are less than compelling. The arguments are in many respects similar to the discussion of the jury's role with regard to determining witness credibility. See infra notes 156-62 and accompanying text.

${ }^{106}$ See id. 
tainting the jury pool to the extent that it would become impossible for the state to supply the impartial jury guaranteed by the Sixth Amendment. Unlike the lying witness and incredulous jury theories, the prejudicial publicity theory is concerned with checkbook journalism's potential effects outside the courtroom.

A state's interest in ensuring that a defendant's trial is not marked by pervasive public prejudice against her is clearly compelling. Extensive public prejudice may lead either to the impossibility of impaneling an impartial jury or to a trial by a partial jury. ${ }^{107}$ If no impartial jury can be impaneled, the Sixth Amendment entitles the defendant to a dismissal of the charges against him. ${ }^{108}$ Trial by a prejudiced jury also violates the Sixth Amendment and, thus, entitles the defendant to a reversal of her conviction. ${ }^{109}$ The Supreme Court has stated that state governments have not only an interest in controlling prejudicial publicity against a defendant, but also a duty to do so. ${ }^{110}$ Thus, even

${ }^{107}$ See infra note 110 (providing examples of the effects of partial juries).

${ }^{108}$ See United States v. Abbott Lab., 505 F.2d 565, 571-72 (4th Cir. 1974) (suggesting that, when an impartial jury cannot be found, dismissal is the appropriate remedy); United States v. Cotton, No. 68-113, slip op. (E.D. Wis. June 11, 1969) (dismissing charges against the defendant because no impartial jury could be impaneled); United States v. Smith, 200 F. Supp. 885, 933 (D.Vt. 1961) (same), rev'd on other grounds, 306 F.2d 596 (1962), cert. denied, 372 U.S. 959 (1963); see also Skelly Wright, Fair Trial-Free Press, 38 F.R.D. 435, 435 (1965). Wright notes,

It is my belief that full recognition of the news media's rights under the First Amendment would prevent a fair trial before an impartial jury as required by the Sixth Amendment in only a precious few cases, and that the dismissal of those cases as non-triable would be small price to pay for the great benefits we all receive ... from the disclosures made in the press ....

Id.

${ }^{109}$ See, e.g., Sheppard v. Maxwell, 384 U.S. 333,363 (1966) (reversing a defendant's conviction because "inherently prejudicial publicity" had saturated the community in which he was tried); Estes v. Texas, 381 U.S 532, 551-52 (1965) (reversing the conviction of a defendant because the live telecasting of his trial rendered the jury partial); Rideau v. Louisiana, 373 U.S. 723, 726 (1963) (holding that the broadcast of a defendant's confession in the days preceding his trial precluded the possibility of any fair proceedings); Irvin v. Dowd, 366 U.S. 717, 728 (1961) (reversing a conviction and stating, "[w]ith his life at stake, it is not requiring too much that petitioner be tried in an atmosphere undisturbed by so huge a wave of public passion").

It is important to remember, however, that "pre-trial publicity-even pervasive, adverse publicity-does not inevitably lead to an unfair trial." Nebraska Press Ass'n v. Stuart, 427 U.S. 539, 554 (1976). Prejudicial publicity leads to an unfair trial only when a defendant can satisfy the Court's tests for actual or presumed juror bias. See supra part I.A (discussing the difficulty of proving actual or presumed bias).

${ }^{110}$ See Nebraska Press Ass' $n, 427$ U.S. at 553 (holding that the government has a duty to protect defendants against the effects of prejudicial publicity); Sheppard, 384 U.S. at 335 (reversing defendant's conviction "because of the trial judge's failure to 
though the incredulous jury theory, by virtue of its subversion of normal jury functions, may not constitute a compelling state interest, the prejudicial publicity theory makes a stronger showing of a compelling governmental interest underlying the statute. As the following sections will demonstrate, however, the statute cannot survive constitutional scrutiny on the strength of the ends it seeks to pursue. Rather, because the statute is content based, it must be narrowly tailored to further those ends.

\section{B. The Content-Based Component of the Checkbook Journalism Statute}

The principle that the government may not "restrict expression because of its message, its ideas, its subject matter, or its content $^{\text {}}{ }^{111}$ is a cornerstone of First Amendment jurisprudence. ${ }^{112}$ The California statute clearly implicates this proscription against content-based restrictions on expression. By its terms, it regulates only speech pertaining to "information obtained as a result of witnessing the event or occurrence."113 Thus, it regulates only speech with a certain subject matter or content. Witnesses face no restrictions on their communications relating to any other topic on which they might choose to speak.

The statute's content-based regulation of this type of speech does not, however, rise to the level of a complete ban. Rather, it merely forbids witnesses from receiving money for certain types of speech. ${ }^{114}$ The Supreme Court has held, however, that contentbased financial disincentives are still suspect under the First Amendment because they discriminate against certain types of speech on the basis of its content or communicative impact, even though they do not ban the speech completely. The Court has held that, because of their content discrimination, these statutes must meet the strict scrutiny standard. For example, in Minneapolis Star v. Minnesota Commissioner of Revenue, ${ }^{115}$ the Court subjected to strict scrutiny, and struck down, a state tax on the cost of paper and

protect [the defendant] sufficiently from the massive, pervasive and prejudicial publicity that attended his prosecution").

${ }^{11}$ Police Dep't v. Mosley, 408 U.S. 92, 95 (1972).

112 See supra part I.B.3 (discussing the constitutional standards for restrictions on speech).

113 Cal. Penal CODE $§ 132.5(\mathrm{~b})$.

${ }^{114}$ See id.

115460 U.S. 575 (1983). 
ink used in publications on the theory that the tax was directed at the communicative impact of speech. ${ }^{116}$ Similarly, the Court refused to uphold an Arkansas statute that taxed general interest magazines, but exempted newspapers and religious, professional, trade, and sports journals, because the tax had the effect of favoring the dissemination of particular ideas over others. ${ }^{117}$ The Court reaffirmed this doctrine in 1991, when it examined New York State's "Son of Sam" law. ${ }^{118}$ That law prevented criminals from profiting through their crimes by requiring that any income generated by an accused or convicted criminal's account of her crimes be deposited in an account for the benefit of her victims and their families. ${ }^{119}$ Justice O'Connor, for the Court, declared that "The Son of Sam law is . . a content-based statute. It singles out income derived from expressive activity for a burden the State places on no other income, and it is directed only at works with a specified content." ${ }^{120}$ After concluding that the interest relied on by the state was not compelling, and that, in any event, the restriction on expression was not narrowly drawn to achieve the stated interest, the Court struck down the statute. ${ }^{121}$

In the same case, the Court established another important proposition: the validity of a content-based financial disincentive to speak does not depend upon which party is subject to the restric-

${ }^{116}$ See id. at 592-93.

${ }^{117}$ See Arkansas Writers' Project, Inc. v. Ragland, 481 U.S. 221, 234 (1987); see also Leathers v. Medlock, 499 U.S. 439, 448-49 (1991) (holding that differential taxation of speakers implicates the First Amendment when the differential treatment is directed at, or presents the danger of suppressing, particular ideas); Grosjean v. American Press Co., 297 U.S. 233, 249-51 (1936) (invalidating a Louisiana statutory tax on select newspapers, all of which happened to be outspoken critics of the governor).

${ }^{118}$ See Simon \& Schuster, Inc. v. New York State Crime Victims Bd., 112 S. Ct. 501 (1991).

${ }^{119}$ See id. at 503.

${ }^{120} \mathrm{Id}$. at 509. The California statute suffers from this same constitutional defect in that it restricts the dissemination of speech with a particular content.

Regulations on speech, however, can be found to be content based even if they do not explicitly single out speech with a particular subject matter. Just last term, the Supreme Court subjected a statute to strict scrutiny because it placed a burden on "expressive activity" by prohibiting governmental employees from receiving compensation for speeches or writings. In striking down this ban on remuneration for speech, the Court declared, "although [the statute] neither prohibits any speech nor discriminates among speakers based on the content or viewpoint of their messages, its prohibition on compensation unquestionably imposes a significant burden on expressive activity." United States v. National Treasury Employees Union, $115 \mathrm{~S}$. Ct. 1003, 1014 (1995).

${ }^{121}$ See Simon E' Schuster, 502 U.S. at 512. 
tion. ${ }^{122}$ Thus, financial disincentives to expression are impermissible regardless of whether they are placed on private individuals seeking to engage in the speech or on media organizations seeking to disseminate it.

California's law banning checkbook journalism is in many respects similar to New York's Son of Sam law, which the Court unanimously held discriminated on the basis of content and thus triggered strict scrutiny review because it imposed a financial burden "only on speech of a particular content." ${ }^{\text {"23 }}$ Under the Son of Sam law, accused or convicted persons were free to sell and keep the profits from any works they produced except those that described their crimes. Similarly, under the California statute, witnesses are free to profit from any communication except those relating to their knowledge of a criminal investigation or trial. Singling out works of a particular content for differential financial treatment is a form of content discrimination. Moreover, the California statute goes beyond merely forbidding profit for certain types of speech; it also prescribes fines and jail time for certain kinds of expression. ${ }^{124}$ By placing not only financial disincentives but also punitive deterrents on the communication of only certain information, California's law against checkbook journalism, like New York's Son of Sam law, discriminates on the basis of content and thus must be reviewed under the strict scrutiny standard. Accordingly, the statute can survive constitutional muster only if it is narrowly tailored to serve a compelling state interest. ${ }^{125}$

California has grounded its asserted interest in the checkbook journalism statute on an interest in preserving fair trial rights. ${ }^{126}$ The statute may serve fair trial interests in three possible ways: deterring witness dishonesty, discouraging jury incredulity of witnesses, and forestalling extensive prejudicial publicity. ${ }^{127}$ In addition, despite complexities undermining the validity of the state's interest in deterring incredulous juries, the state still could argue

${ }^{122}$ See id. at 503 ("[T] disincentives on speech does not vary with the identity of the speaker.").

${ }^{123} \mathrm{Id}$. at 509.

${ }^{124}$ See CAL. PENAL CODE $\$ 132.5$ (e) (providing that the sale of information relating to criminal investigations or prosecutions is punishable by fines of up to three times the amount the witness received for the story and up to six months in jail).

${ }^{125}$ See, e.g., supra notes 85-88 and accompanying text

${ }^{126}$ See supra note 32 and accompanying text (discussing the rationale for the California statute).

${ }^{127}$ See supra part II.A (discussing how the statute relates to the furtherance of these interests). 
that its interest in preserving fair trial rights is compelling under the theories of excluding false testimony and minimizing prejudicial publicity, thereby meeting the first prong of strict scrutiny analysis. ${ }^{128}$ Accordingly, the next section proceeds to the second prong of the strict scrutiny analysis, examining whether the statute is narrowly tailored to protect compelling state interests.

\section{The Means to Securing a Fair Trial Under the Narrow Tailoring Test}

The lying witness theory addresses the possible introduction of unreliable evidence-evidence tainted by witnesses' financially induced embellishments-at trial. The incredulous jury theory addresses the converse problem: the possible exclusion of reliable evidence, which a jury might discount on the suspicion that witnesses who have been paid by the press are untrustworthy. Both of these fair trial interests address the accuracy of the evidentiary process. Because of the similarity of these two theories in seeking to ensure the integrity of the evidentiary process, the degree to which the statute is narrowly tailored to ameliorate these perceived threats will be examined together. The prejudicial publicity theory, by contrast, is directed to aspects of the fair trial right extrinsic to fact-finding processes. Accordingly, its fate under the narrow tailoring prong of the First Amendment jurisprudence will be discussed separately.

1. Under the Lying Witness and Incredulous Jury Theories

To be found a constitutionally valid content-based restriction on speech, the California statute must be narrowly tailored to the compelling state interest of preserving fair-trial rights. Two possible means by which it might serve that interest are by discouraging witness dishonesty or by mitigating jury incredulity, thereby preventing juries from relying on false or exaggerated testimony or discrediting otherwise reliable statements. To survive the strict scrutiny required of content-based restrictions, the statute must demonstrate a "tight fit" between the ends pursued and the means used to pursue them. Means that are either overinclusive or underinclusive in the speech they restrict fall afoul of the First Amendment. ${ }^{129}$ Similarly, when allowing more speech would avert

${ }^{128}$ See supra part II.A.

${ }^{129}$ See supra notes 85-87 and accompanying text (discussing Supreme Court cases 
the harms associated with the speech sought to be restricted, then the speech restriction will likely fail the narrow tailoring test. ${ }^{130}$ As the following analysis demonstrates, the California statute is rife with problems under these narrow tailoring requirements. First, the harm sought to be redressed, namely the tainting of the evidentiary process, can be averted with further speech. Second, the statute lacks a "tight fit" with the avowed goal of protecting the integrity of the fact-finding process, because the statute itself subverts fundamental elements of that process. Finally, the statute fails the narrow tailoring test because it is underinclusive.

\section{a. Less Restrictive Means in Similar Situations}

One way of showing that a governmental action restricting expression is not narrowly tailored to achieve its ends is to demonstrate that those ends could be achieved in other ways that do not restrict freedom of speech. ${ }^{131}$ According to Professor Laurence Tribe, "whenever the harm feared could be averted by a further exchange of ideas, governmental suppression is conclusively deemed unnecessary." 132

To see how the harms of witness dishonesty and jury incredulity can be averted by a further exchange of ideas in a way that does not restrict freedom of expression, it is helpful to compare media-paid witnesses to other categories of trial participants who are similarly situated. ${ }^{133}$ Perhaps the clearest analogy is to expert witnesses, who are routinely paid for their testimonies. ${ }^{134}$ The same fears motivating the ban on checkbook journalism-that it induces witnesses to lie or exaggerate, or that it leads the jury to assume that an otherwise credible witness is lying or exaggerating-appear

applying strict scrutiny).

${ }_{130}$ See supra notes $84-88$ and accompanying text (discussing the "narrowly tailored" requirement).

${ }_{131}$ TRIBE, supra note $83, \S 12-8$, at $833-34$ (discussing the basis for invalidating a statute).

${ }^{132} I d$. (emphasis omitted).

${ }^{139}$ Editorial pages have noted the comparison between media-paid witnesses and other trial participants whose credibilities are in question. See Erwin Chemerinsky, Should Witnesses Be Allowed to Sell Their Stories Before the Trial?, L.A. TIMES, Aug. 22, 1994, at B7 (concluding that witnesses should be able to sell their stories); Muzzling Witnesses No Guarantee of Fair Trial, USA TODAY, Sept. 30, 1994, at 10A (disagreeing with the rationale of the California statute).

${ }^{134}$ See FED. R. EVID. 706(b) (entitling court-appointed experts to reasonable compensation); 31A AM. JUR. 2D Witnesses § 19-25 (1992) (contemplating that expert witnesses may be paid for their testimony). 
to be equally present when a paid expert testifies on behalf of one party. ${ }^{135}$

Yet, rather than ban the practice of paying expert witnesses, the system has devised a simple and effective solution that does not restrict freedom of expression: cross-examination. Cross-examination has been an essential instrument in fulfilling the truthfinding function of our adversary system for over two hundred years. ${ }^{136}$ In criminal cases, the defendant's right to cross-examine adverse witnesses is grounded in the Bill of Rights. ${ }^{137}$ The critical purpose of cross-examination is to elicit "the facts which diminish the personal trustworthiness of the witness." 138

An attorney may cross-examine a witness to elicit any bias the witness has in favor of a party, any prejudice the witness harbors against a party, and any personal interest the witness has in the outcome of the trial proceeding. ${ }^{139}$ This kind of information furthers the truth-finding process by helping the fact finder decide how much credibility to attach to a witness. "Cross-examination," the Supreme Court has stated, "is the principal means by which the believability of a witness and the truth of his testimony are tested." 140

In addition to substantive challenges to their testimony, experts may be cross-examined about any financial interests implicated in the instant case, employment relationships with a party or real party in interest in the suit, or prior testimony for the same party or attorney in other litigation. ${ }^{141}$ Anticipation of a persistent cross-

${ }^{135}$ See generally Samuel R. Gross, Expert Evidence, 1991 WIs. L. REv. 1113, 1168 (listing several grounds on which expert witnesses may be impeached and stating that financial bias is one that has "special bite"); Jeffrey J. Parker, Note, Contingent Expert Witness Fees: Access and Legitimacy, 64 S. CAL. L. REv. 1363, 1385-1388 (1991) (discussing several forms of financial bias that are likely to influence expert witnesses).

${ }^{136}$ See MCCORMICK ON EvideNCE 30 (John W. Strong ed., 4th ed. 1992).

${ }^{137}$ See U.S. CONST. amend. VI. This provision, the Confrontation Clause, has been interpreted as guaranteeing criminal defendants the right to cross-examine witnesses against them to test the credibility of their testimony. See generally Pointer v. Texas, 380 U.S. 400,403 (1965) ("We hold today that the Sixth Amendment's right of an accused to confront the witnesses against him is likewise a fundamental right and is made obligatory on the States by the Fourteenth Amendment.").

${ }^{138} 5$ JOHN H. WIGMORE, EVIDENCE IN TRIALS AT COMMON LAW $\S 1368$, at 37 (Chadbourn ed., rev. ed. 1974). The other primary purpose of cross-examination is to draw out any "remaining and qualifying circumstances" of the witness's testimony. 5 Id. at 36.

${ }^{139}$ See, e.g., ERIC D. Green \& Charles R. Nesson, Problems, Cases, and MATERIALS ON EVIDENCE 109-27 (2d ed. 1994) (discussing methods of attacking witness credibility).

${ }^{140}$ Davis v. Alaska, 415 U.S. 308, 316 (1974).

${ }^{141}$ See MCCORMICK ON EVIDENCE, supra note 139, at 22 (summarizing proper 
examiner may motivate an expert not to lie or exaggerate while testifying on direct examination. The appearance of dishonesty or unreliability may irreparably damage her reputation, severely curtailing the expert's ability to make a living. ${ }^{142}$ Deterrents such as perjury prosecutions ${ }^{143}$ and libel suits ${ }^{144}$ provide further checks on dishonest testimony.

With these safeguards in place the jury can observe "the greatest legal engine ever invented for the discovery of truth"145 in action and adjudge whether the expert witness is credible or whether financial incentives to proffer particular testimony have rendered the testimony unreliable. In the same manner, cross-examination of a media-paid fact witness can help the jury ascertain whether the witness's story remains credible despite the remuneration, or whether it appears to be fabricated or exaggerated to exploit media

cross-examination questions regarding an expert's financial interests in her testimony); Michael H. Graham, Impeachment of Expert Witness-Financial Interest, 21 AM. JUR. PROOF OF FACTS 2D 73 (1980) (discussing expert-witness bias caused by financial interests in the trial outcome).

${ }^{142}$ Arguably, the fact that expert witnesses depend on their credibility for their livelihood makes cross-examination a more effective deterrent against lying expert witnesses than against lying fact witnesses. This argument, however, assumes that fact witnesses are indifferent to the judgments of those around them. Fact witnesses, like anyone else, have an interest in preserving their reputations, and thus would fear being exposed as unreliable or dishonest before their communities, employers, colleagues, families, and friends, even if their livelihood is not directly linked to the credibility of their testimony. There is little reason to assume that the average fact witness's incentive to maintain her personal reputation is significantly weaker than the average expert witness's incentive to maintain her professional reputation.

Indeed, expert witnesses may have more actual or perceived reasons to stand by a false or exaggerated testimony than media-paid witnesses. Precisely because her livelihood depends on making certain statements, the expert cannot retreat from her prior testimony under the pressure of cross-examination without great risk to her future career as an expert witness. Media-paid fact witnesses, however, are likely to be one-time witnesses to crimes who may have already exploited their stories to their fullest profit-making potential. Media-paid witnesses would be more likely to render truthful testimony in court when faced with the pressures of taking an oath and enduring cross-examination, having no further interest in maintaining exaggerated testimony. See, e.g., Weinstein, supra note 3, at A2 (reporting that witnesses in the high-profile Michael Jackson investigation rendered testimony in depositions that was less sensational than statements they made to the media). Thus, the lying witness and incredulous jury problems are no more severe with media-paid witnesses than with expert witnesses, and in some instances may be less severe.

${ }^{143}$ See generally 18 U.S.C. $\$ 1621$ (1994) (providing that perjury in federal court is punishable by fine and imprisonment of up to five years).

${ }^{144}$ See, e.g., New York Times v. Sullivan, 376 U.S. 254 (1964) (defining standards for libel cause of action).

${ }^{145} 5$ WIGMORE, supra note 138, § 1367. 
sensationalism. Factors such as the credibility of the story itself, the amount of corroborating testimony or evidence, the witness's demeanor, and the degree to which the story has remained consistent throughout dealings with authorities and with the media can help the jury to determine the ultimate reliability of the testimony.

Another useful analogue to the checkbook journalism witness is the criminal defendant who plea-bargains with the government, offering testimony to aid the prosecution at another trial in exchange for clemency. The plea-bargaining defendant raises concerns similar to those raised by the paid expert and the witness who profits from checkbook journalism. ${ }^{146}$ All three have incentives to make particular statements, raising doubts about their credibility. For example, a defendant who was part of a conspiracy and who accepted a reduced charge or a grant of immunity in exchange for testimony inculpating coconspirators has a clear incentive to give her benefactors-the prosecution-evidence sufficient to secure convictions against the other conspirators. In addition to the risk of the witness lying or exaggerating to give the prosecution what it wants, there is also a rational fear that the jury will not believe the testimony of the plea-bargainer because of her interest in the case, as with paid experts or witnesses who have taken money from tabloids. Indeed, the lying witness and incredulous jury concerns are even stronger with respect to the pleabargaining witness than with expert witnesses or fact witnesses who have taken money from the media, because the plea-bargaining witness's interest in standing by particular statements goes beyond monetary gain and implicates her very liberty.

Yet, rather than ban the practice of plea-bargaining because it arguably taints the evidentiary process, the Supreme Court has wholeheartedly endorsed it. ${ }^{147}$ Courts commonly allow the testimony of a plea-bargaining witness to be used against other defendants. ${ }^{148}$ Courts, however, have not been blind to the aforemen-

${ }^{146}$ See Yvette A. Beeman, Note, Accomplice Testimony Under Contingent Plea Agreements, 72 CORNELL L. REv. 800, 802, 826 (1987) (arguing that "[p]lea bargains conditioned upon indictment, conviction, or prosecutorial satisfaction with testimony" encourage perjury and other unreliable testimony).

${ }^{147}$ See, e.g., Santobello v. New York, 404 U.S. 257, 260 (1971) (treating pleabargaining as an essential means of securing testimony).

${ }_{148}$ See, e.g., Fallen v. United States, 220 F.2d 946, 948 (5th Cir. 1955) (holding testimony of a conspirator admissible against coconspirator); State v. Carey, 206 S.E.2d 213, 219 (N.C. 1974) (noting that declaration of one conspirator is competent 
tioned dangers of the practice. In fact, most have been acutely aware of these dangers but have regulated them with the tool of cross-examination. A witness who has plea-bargained may be impeached on cross-examination in numerous ways. The defendant against whom the plea-bargaining witness is testifying has the right to ask the witness whether he has been granted immunity or other special treatment, ${ }^{149}$ or has bought his peace from the prosecution, ${ }^{150}$ and to argue that his testimony is unreliable because of the likelihood that it is fashioned to curry favor with the prosecution. ${ }^{151}$

Cross-examination of this scope thus minimizes the risk that juries will rely on evidence tainted by the incentives to lie or exaggerate inherent in plea-bargaining. Moreover, cross-examination allows the jury to decide the degree of skepticism with which it receives the testimony. Instead of restrictions which rashly discount the testimony of every plea-bargaining witness because of potential incentives to lie, cross-examination allows the jury to assess witnesses' demeanor on the stand ${ }^{152}$ and consistency in the face of intense questioning. They jury can then decide how much credibility to attribute to each witness. This same process would

evidence against other conspirators); David A. Jones, Negotiation, Ratification, and Rescission of the Guilty Plea Agreement: A Contractual Analysis and Typology, 17 DuQ. L. REv. 591, 605-06 (1978-1979); James M. Smith \&c William P. Dale, Note, The Legitimation of Plea Bargaining: Remedies for Broken Promises, 11 AM. CRIM. L. REv. $771,772-73$ (1973).

${ }^{149}$ See, e.g., Spaeth v. United States, 232 F.2d 776, 779 (6th Cir. 1956) (affirming that it is "entirely proper on cross-examination of a witness 'to show a belief or even only a hope on his part that he will secure immunity or a lighter sentence, or any other favorable treatment, in return for his testimony"); People v. Bote, 33 N.E.2d 449, 451-52 (IIl. 1941) (holding that defendant must be allowed to cross-examine codefendant on conditions of the plea bargain that the prosecutor used to convince codefendant to testify).

${ }^{150}$ See, e.g., State v. Ponthier, 346 P.2d 974, 980 (Mont. 1959) (upholding the right of cross-examination to elicit whether the witness has received favors from the prosecution).

${ }^{151}$ See, e.g., Henderson v. State, 652 S.W.2d 16, 18 (Ark. 1983) (holding that defense counsel was entitled to ask on cross-examination "What kind of deal are you getting for yourself?" and finding reversible error in trial court's denial of opportunity to elicit answer to that question for the jury's consideration); People v. Buchanan, 393 N.Y.S.2d 810, 812 (App. Div. 1977) (recognizing ways in which testimony of indicted witness could be unreliable).

${ }^{152}$ The Court has explicitly stated that it is proper for the jury to take into account the appearance, manner, and demeanor of the witness while testifying. See California v. Green, 399 U.S. 149, 158 (1970) (acknowledging admissibility of out-of-court statements made by witness when declarant had been subject to full and effective cross-examination). 
effectively redress the lying witness and incredulous jury problems raised by checkbook journalism. Upon cross-examination, the jury could decide whether the totality of factors, including the sale of her story to the press, suggests that the witness and her testimony are reliable.

The problem of checkbook journalism witnesses should not be treated any differently from its closest analogues in our adversary system. If cross-examination sufficiently safeguards against the dangers inherent in the induced testimony of paid experts or pleabargainers, then it should sufficiently safeguard against the identical dangers inherent in the practice of checkbook journalism. Where experts receive money and plea-bargainers receive clemency in return for their testimony, the state has not regulated the source of the inducement. Neither has the state forbidden payment to expert witnesses or restricted plea bargaining as a means of eliciting testimony against other defendants. Rather, the state has found cross-examination to be an effective means of discrediting unreliable testimony or dispelling the appearance of impropriety surrounding otherwise reliable induced testimony. Cross-examination could cure the fair-trial concern for evidentiary integrity in the checkbook journalism context with equal effectiveness. Thus, the statute is poorly tailored to remedy any potential lying witness or incredulous jury problems, unnecessarily fettering the dissemination of speech instead of pursuing less restrictive alternatives. ${ }^{153}$ This lack of narrow tailoring makes the statute suspect as a form of contentbased discrimination against the message imparted by checkbook journalism witnesses, rather than a narrowly tailored means of pursuing a legitimate state interest in the integrity of the factfinding process.

\section{b. Inconsistency with Underlying Goals}

The California statute suffers from another defect in the means by which it pursues its goal of ensuring fair trials: the means compromise not only First Amendment interests, but also Sixth Amendment interests. It is fundamental to our system of justice that the role of the jury in criminal and civil trials is to decide issues of fact. ${ }^{154}$ The Supreme Court has underscored its importance,

${ }^{155}$ See supra note 87 and accompanying text (explaining that a governmental action that restricts expression unnecessarily cannot survive constitutional review under the strict standard).

${ }^{154}$ See, e.g., Bailey v. Central Vermont R.R., 319 U.S. 350, 353 (1943) (explaining 
noting that the role of the jury as a fact-finding body "is of such importance and occupies so firm a place in our history and jurisprudence that any seeming curtailment of the right to a jury trial should be scrutinized with the utmost care. ${ }^{n 155}$ In criminal cases, trial by jury serves as a check on government oppression by assuring that the relevant community participates in the determination of guilt or innocence. ${ }^{156}$ It also provides a "fair and equitable" means of resolving issues of fact. ${ }^{157}$

The credibility of a witness is a quintessential issue of fact. For this reason courts have almost universally held that credibility is the sole province of the jury, ${ }^{158}$ and have disallowed testimony by experts as to whether the jury should believe a witness or not. ${ }^{159}$ By enacting legislation that declares that certain conduct inexorably erodes the credibility of a witness, the state of California has substituted its own blanket judgment regarding what determines witness credibility for the individualized judgments of juries. In so doing, the state has impinged on a fundamental aspect of the Sixth Amendment-the right to a trial by a jury of one's peers. Paradoxically, then, the state has abrogated Sixth Amendment rights while purporting to further those same guarantees. ${ }^{160}$ A statute that

that the "jury is the tribunal under our legal system to decide" factual questions about which reasonable persons might differ); Baltimore \& Carolina Line v. Redman, 295 U.S. 654, 657 (1935) (stating that the Bill of Rights incorporates the central role of the jury in determining issues of fact).

${ }_{155}$ Beacon Theatres, Inc. v. Westover, 359 U.S 500, 501 (1959); see also Parsons v. Bedford, 28 U.S. 433, 445 (1830) ("The trial by jury is justly dear to the American people. It has always been an object of deep interest and solicitude, and every encroachment upon it has been watched with great jealousy.").

${ }^{156}$ See Williams v. Florida, 399 U.S. 78, 100 (1970) ("[T] he essential feature of a jury ... lies in the interposition between the accused and his accuser of the commonsense judgment of a group of laymen, and in the community participation and shared responsibility that results from that group's determination of guilt or innocence."); Duncan v. Louisiana, 391 U.S. 145, 156 (1968) ("Providing the accused with the right to be tried by a jury of his peers gave him an inestimable safeguard against the corrupt or overzealous prosecutor and against the compliant, biased, or eccentric judge.").

${ }^{157}$ Colgrove v. Battin, 413 U.S. 149, 157 (1973).

${ }^{158}$ See State v. Saldana, 324 N.W.2d 227, 231 (Minn. 1982) (noting that once a witness is deemed competent, expert opinions concerning the witness's reliability in distinguishing truth from fantasy are generally inadmissible because such opinions invade the jury's province to make credibility determinations).

${ }^{159}$ See United States v. Jackson, 576 F.2d 46, 49 (5th Cir. 1978) (upholding the exclusion of expert testimony regarding a witness's credibility because such testimony would invade the province of the jury); United States v. Wertis, 505 F.2d 683, 685 (5th Cir. 1974) (same); United States v. Barnard, 490 F.2d 907, 912 (9th Cir. 1973) ("Credibility ... is for the jury-the jury is the lie detector in the courtroom.").

${ }^{160}$ See supra part II.A (noting that the California legislature invoked Sixth 
compromises an important aspect of the very interest it claims to further can hardly be said to be narrowly tailored to furthering that interest.

\section{c. Underinclusiveness}

There is a final sense in which the statute is not narrowly tailored to counteract the dangers of witness dishonesty and jury incredulity. Even if cross-examination were not always a sufficient safeguard against these risks, necessitating some restriction on speech to protect fair trial interests in mitigating these risks, the statute's underinclusiveness renders it ill suited to redress the potential harms wrought by dishonest witnesses and incredulous juries.

There are numerous reasons why a witness in a particular criminal proceeding might give fabricated or exaggerated testimony. For example, a witness might be prejudiced against the defendant, biased in favor of the defendant, or personally interested in the outcome of the case. ${ }^{161}$ A state determined to rectify this problem would presumably take some action to discourage witness dishonesty, whatever the witness's motivation, through a measure that would apply to any witness with an incentive to lie or exaggerate.

California, however, has not done so. The statute has singled out one small class of witnesses whose potential incentive to utter untruthful testimony derives from speaking on a particular subject matter, and has attempted to discourage them from exercising this constitutional right by placing a content-based burden on the dissemination of this speech. The statute has done nothing to discourage false testimony among those witnesses whose incentives stem from anything other than checkbook journalism. The gross underinclusiveness of the statute makes it poorly tailored to further California's interest in preventing false testimony in its courts. Indeed, the statute's underinclusiveness suggests that the motivation for enacting it was less a concern with false testimony than an aversion to the content of the speech often expressed through checkbook journalism. ${ }^{162}$ This governmental attempt to disfavor

Amendment rights as the purpose underlying the checkbook journalism statute and analyzing ways in which the statute may further Sixth Amendment concerns).

${ }^{161}$ See supra note 142 and accompanying text (discussing sources of witness bias).

${ }^{162} \mathrm{~A}$ finding that a legislature was motivated by desire to suppress speech of a particular content can be grounds for invalidating the legislation. See United States v. Eichman, 496 U.S. 310, 318 (1990) (striking down the Flag Protection Act of 1989 
certain speech it finds distasteful goes to the heart of what the First Amendment forbids. ${ }^{163}$

The statute is as underinclusive in its response to harms associated with incredulous juries as it is in redressing problems with dishonest witnesses. There are as many reasons a jury might discount the value of a witness's testimony as there are reasons a witness might not be completely forthright. The statute is underinclusive because it targets only one class of witnesses of whom juries might be incredulous. ${ }^{164}$ It is thus not narrowly tailored to serve the state's interest and, again, leads one to conclude that the state's ostensible concern with incredulous juries is really a screen for disgust with the speech involved in checkbook journalism.

\section{Under the Prejudicial Publicity Theory}

In light of the Supreme Court's interpretation of the Sixth Amendment, a defendant can rarely prove that juror prejudice rose to a level that implicated her Sixth Amendment rights. ${ }^{165}$ The fair-trial rights embodied in that provision do not, after all, require that a jury be entirely unfamiliar with a case, but rather require only that the jury be able to set aside any preconceived impressions and "render a verdict based on the evidence presented in court." 166 The exceptional character of the case that will support an argument for juror prejudice signals another way in which the statute is not narrowly tailored.

on the grounds that the statute, even if content neutral on its face, was motivated by content-based distaste for speech communicating certain ideas).

${ }^{163}$ See supra part I.B.3 (noting the First Amendment's concern with preventing the government from suppressing the expression of certain ideas). The risk of governmental use of underinclusive speech restrictions to suppress ideas or information it considers objectionable is one of the central reasons the Court has given for making underinclusiveness a fatal defect in regulations of expression. See supra note 87 (explaining the First Amendment problem of underinclusive speech restrictions).

${ }^{164}$ As noted earlier, the state's claim that it has any legitimate interest in preventing juror incredulity is suspect, given the jury's fundamental constitutional role in weighing the credibility of the evidence. See supra notes 156-62 and accompanying text.

${ }^{165}$ See supra part I.A (summarizing Supreme Court jurisprudence limiting the scope of Sixth Amendment fair-trial guarantees).

${ }^{166}$ Irvin v. Dowd, 366 U.S. 717, 723 (1961); see also supra part I.A (describing Sixth Amendment jurisprudence and noting its tendency to tolerate a significant degree of juror exposure to the facts of the case before finding a juror too biased for Sixth Amendment purposes). 
The statute by its terms applies to any person who "knows or reasonably should know" that she may be called as a witness in any criminal prosecution. ${ }^{167}$ It applies to every potential witness in every potential criminal case in the state of California. However, only a small fraction of the total number of criminal prosecutions in California will be attended by circumstances that justify concern about prejudicial publicity and tainted jury pools. For example, there is no reason to assume that the testimony of every witness who contracts with the media to sell information will be adverse to the defendant. ${ }^{168}$ The stories of some media-paid witnesses will tend to exculpate rather than inculpate the defendant and will tend to allay rather than inflame public prejudice. The testimonies of other media-paid witnesses may be adverse to the defendant but unlikely to arouse the amount or kind of publicity that would jeopardize fair-trial rights. For instance, the media might pay an otherwise reluctant witness a modest amount to come forward with a story that draws short-lived or local public attention, but that would have faded into insignificance by the time of trial and would never have been publicized in the geographic area where the trial is to be held. In those cases, the checkbook journalism statute would have removed speech from the public debate on the basis of its content, without furthering its avowed Sixth Amendment concerns in any rational way. These examples demonstrate how the statute is not narrowly tailored to prevent prejudicial publicity. It is overinclusive because it burdens the free speech rights of witnesses in cases where there is little or no threat of extensive prejudicial publicity.

${ }^{167}$ Cal. Penal Code $\$ 132.5(b)$.

${ }^{168}$ Al Cowlings, O.J. Simpson's lifelong friend and companion during the televised low-speed freeway chase, has reportedly been offered "up to $\$ 1$ million for his story," but has so far declined all offers. Weinstein, supra note 3, at A1. Had he accepted one, however, his story would have been favorable to the defendant, as Cowlings has staunchly maintained his belief in Simpson's innocence. See Robert P. Laurence, Our Exclusive! O.J.! TV Tabloids!, SAN DIEGo TRIB., Feb. 20, 1995, at D1.

Rumors have circulated that another witness in the Simpson trial, Rosa Lopez, was paid $\$ 5000$ by a tabloid for her story, although these speculations remain unsubstantiated. See Rosa Lopez Scheduled to Resume Cross-Examination Today (NPR radio broadcast, Mar. 3, 1995). Lopez's testimony places Simpson's car at his residence during the time the murders were allegedly committed and thus serves as an alibi for the defendant. See id. These are two recent examples of potential mediapaid witnesses whose unrestricted contact with the press would not prejudice the defendant's right to receive a fair trial. 
Instituting such an overinclusive statute may also preclude speech which might contribute to public debate about the criminal process and its treatment of criminal defendants and does not unduly prejudice jurors. In such instances, the statute's overbreadth would compromise the First Amendment's self-governance ${ }^{169}$ and marketplace of ideas rationales, ${ }^{170}$ while failing to further Sixth Amendment fair-trial concerns.

Alternative means of curing prejudicial publicity problems are available. First, courts have at their disposal a number of mechanisms designed to prevent prejudice to a defendant, none of which restrict free speech. Courts can change the venue of a trial or postpone it. Courts may also sequester the jurors and give careful jury instructions on which factors the jury may consider in reaching its verdict. ${ }^{171}$ These mechanisms will often suffice to ensure that a trial will meet the Sixth Amendment guarantee of trial by an impartial jury. ${ }^{172}$ In the numerous cases where these protective measures could ensure an impartial jury, no speech would suffer a content-based disincentive to its dissemination, and the public debate would proceed unfettered.

In the cases in which prejudicial publicity would be particularly intense, a judge still has the option of imposing an order forbidding an anticipated witness from accepting payment for her testimony. The judge could determine, either sua sponte or on a party's motion, that the case poses a particularly severe risk of prejudicial publicity, which warrants a restriction on accepting compensation for speech related to the trial.

Although such judicial orders would still constitute a contentbased restriction on free speech and would be subject to strict scrutiny, ${ }^{173}$ these case-by-case orders would be more narrowly tailored to mitigating the harm of prejudicial publicity and, thus, would fare better under constitutional scrutiny than the California

${ }^{169}$ See supra part I.B.2 (explaining the self-governance rationale underlying the First Amendment).

${ }^{170}$ See supra part I.B.1 (explaining the marketplace of ideas rationale).

${ }^{171}$ See supra notes 22-28 (describing various mechanisms of ensuring fair trials).

${ }^{172}$ See Irvin v. Dowd, 366 U.S. 717, 723 (1961) (holding that to meet Sixth Amendment standards of impartiality, a juror need not have been wholly insulated from the case, as long as the juror is impartial enough to decide the case on the evidence at trial).

${ }^{173}$ See supra part II.B (explaining that a financial disincentive directed at the dissemination of speech with a particular subject matter or content, such as that embodied in the California statute, is a content-based restriction that may only survive strict scrutiny by being narrowly tailored to achieve a compelling state interest). 
statute. Whereas the statute automatically presumes a risk of prejudicial publicity in any criminal trial, judicial orders would be predicated on a specific finding that speech-neutral mechanisms are insufficient to preserve an impartial jury. These restrictions would thus be the exception rather than the rule and would consequently suppress speech only when absolutely necessary, avoiding the overinclusiveness problem that plagues the current statute. Under this system, only those witnesses who would actually jeopardize the defendant's right to a fair trial would be forbidden from selling information, whereas all other witnesses would be free to disseminate their speech on whatever terms they chose. Furthermore, although the statute's restrictions apply to all speech related to the trial and last throughout the duration of the trial, a case-specific approach would allow restrictions only on the parts of a witness's story that a judge would deem likely to be prejudicial and only during the time when the speech would be likely to have prejudicial effects. A judicially managed, case-specific approach to this problem would thus infringe upon free speech rights only to the extent necessary to serve the compelling government interest of preserving fair-trial rights. A reviewing court would thus be more likely to find this case-specific restriction to be narrowly tailored in satisfaction of First Amendment standards.

This case-specific approach, despite curing the major constitutional problems with California's statutory approach, would nonetheless present several problems of its own. First, the judge may not always be able to restrict prejudicial speech to the narrowest degree necessary. The case-by-case approach would require some speculation, because a judge could never know with certainty which individuals would actually testify at trial and what degree of public prejudice their story, if sold to the press, would generate. Judicial orders could, therefore, also be overinclusive by restricting payment for testimony from individuals who would not be called as witnesses or from actual witnesses whose statements would not prejudice the trial publicity against the defendant to an impermissible degree. Although judicial orders may, at times, be overreaching, they would, nonetheless, be more tailored in scope than statutes that forbid all witnesses from speaking on the subject of their testimony. More speech would thus reach the public arena, making the case-specific alternative more palatable under the First Amendment.

A second possible criticism of the judicial order alternative is that it is more narrowly tailored than the statute only because it is 
more content discriminatory. Reliance on judicial orders could pose an even greater risk of content discrimination than the statute's restriction on speech related to criminal trials because judges could unilaterally determine what information could and could not be released to the public. For example, a judge could restrict the sale of testimony exposing police misconduct but permit the sale of testimony incriminating defendants.

The Supreme Court is sharply divided on whether a statute that restricts certain forms of expression generally is more or less repugnant under the First Amendment than an individually directed order which, despite restricting less speech overall, permits discrimination against the message sought to be communicated by the individual subject to the judicial order. ${ }^{174}$ This ambiguity, however, is of minimal relevance under the First Amendment because, although the relative degree of content discrimination brought about by a generally sweeping statute versus an individually directed judicial order is subject to debate, both types of restrictions are content based, and thus both are subject to the same strict scrutiny. The Court has never formulated a sliding scale test whereby a more discriminatory state action must be deemed more narrowly tailored or assessed under "stricter" scrutiny. Rather, once the Court determines that a speech restriction is content based, it applies the same strict scrutiny standard. Under this strict scrutiny standard, both the statute and the judicial order would be deemed content based. The statute, however, would also be considered grossly overbroad because it suppresses speech in many instances in which

${ }^{174}$ The Justices' diverging views on this subject were recently explicated in Madsen v. Women's Health Ctr., 114 S. Ct. 2516 (1994). The majority, in an opinion by Chief Justice Rehnquist, maintained that injunctions, even when they are content neutral, "carry greater risks of censorship and discriminatory application than do general ordinances" and, therefore, should be subject to a slightly more rigorous standard than the "time, place, and manner" analysis the Court would employ in evaluating a comparable ordinance of general applicability. Id. at 2524. Justice Stevens, on the other hand, argued in a dissenting opinion that injunctions generally follow from some violation or threatened violation of law, and so "should be judged by a more lenient standard than legislation." Id. at 2531 (Stevens, J., dissenting). Finally, Justice Scalia, in a dissenting opinion joined by Justices Kennedy and Thomas, contended that injunctions, even when content neutral, should be assessed under the same standard as content-based legislation-the strict scrutiny standard. See id. at 2538 (Scalia, J., dissenting). Scalia offered three reasons for this conclusion: injunctions may be used to target particular ideas for suppression; injunctions are the "product of individual judges" who may bear some ill will toward the parties at whom their injunctions are directed; and injunctions are procedurally more difficult to challenge than statutes. See id. 
no threat of prejudice threatens the protections afforded by the Sixth Amendment. The judicial order approach, on the other hand, would be viewed as narrowly tailored because it restricts speech only to the extent necessary to preserve Sixth Amendment concerns. Thus, despite the opportunity for content discrimination inherent in judicial orders, this alternative permits narrow tailoring, allowing it to survive constitutional examination. ${ }^{175}$

A third possible objection to this proposal is that it would be more difficult to administer than a statutory ban. The proposal would indeed require judges to invest time and resources in deciding whether to issue "no-payment" orders in individual cases and in monitoring compliance with outstanding orders. Still, the administrative inconvenience should be negligible. Only a small percentage of cases would attract the amount and kind of attention that would justify such concerns about excessive prejudicial publicity; most of these could be cured with mechanisms other than restraints in speech. ${ }^{176}$ Hence, a judge would rarely find it necessary to resort to an order of this kind.

Moreover, a ban would not be self-executing. Judges would still be charged with determining whether a particular witness had violated the California statute. It would be easy to imagine ambiguities that a witness could exploit to evade penalties under the statute, such as whether the compensation she received from a media outlet was compensation for her story or for another purpose, ${ }^{177}$ whether she knew or reasonably should have known that the event or occurrence she witnessed was a crime, ${ }^{178}$ or whether she knew or should have known that she would be called as

${ }^{175}$ See Shelton v. Tucker, 364 U.S. 479, 488 (1960) (holding that a governmental objective "cannot be pursued by means that broadly stifle fundamental personal liberties when the end can be more narrowly achieved. The breadth of the legislative abridgement must be viewed in the light of less drastic means for achieving the same basic purpose.").

For more recent cases in which the Court has formulated the strict scrutiny standard in terms of the least restrictive means test, see Sable Communications, Inc. v. FCC, 492 U.S. 115, 126 (1989) ("The Government may . . . regulate the content of constitutionally protected speech in order to promote a compelling interest if it chooses the least restrictive means to further the articulated interest."); Burson v. Freeman, 112 S. Ct. 1846, 1857-58 (1992) (applying this test and upholding a restriction on political speech near polling places).

${ }^{176}$ See supra notes $22-28$ and accompanying text (enumerating mechanisms that can cure most threats to fair-trial rights without resorting to speech restrictions).

177 See CAL. PENAL CODE § 132.5(a) (proscribing payment for information).

${ }^{178}$ The statute is not applicable if an individual does not know, and should not reasonably know, that the event or occurrence she observed was a crime. See id. 
a witness. ${ }^{179}$ Thus, whether the state's approach to regulating the harms associated with checkbook journalism is a categorical statutory restriction or a case-by-case deployment of judicial orders, there will be some added costs in terms of judicial administration. Any marginal increase that might accompany a case-by-case approach is well justified by the lesser affront to First Amendment rights it entails. ${ }^{180}$

\section{Alternatives CoMport WITH FirST AMENDMENT RATIONALES}

This Part demonstrates that the suggested alternative means of achieving the statute's ends, ${ }^{181}$ in addition to being more congruent with contemporary First Amendment doctrine, also better comport with the traditional policies and rationales underlying the First Amendment.

\section{A. Cross-Examination}

Allowing witnesses to sell what they please to the media and to be thoroughly cross-examined and impeached for doing so is consistent with the marketplace of ideas rationale of the First Amendment. ${ }^{182}$ Rather than prohibiting a witness from injecting information into the arena of public debate via the media, the marketplace of ideas rationale would advocate exposing falsifica-

179 The statute is not applicable if the individual does not know, and should not reasonably know, that she may be required to participate as a witness in a criminal proceeding. See id.

${ }^{180}$ See United States v. National Treasury Employees Union, 115 S. Ct. 1003, 1017 (1995) (rejecting government's argument defending a total ban because "a wholesale prophylactic rule is easier to enforce than one that requires individual ... determinations" and holding that a "blanket burden on the speech of nearly 1.7 million federal employees requires a much stronger justification than the Government's dubious claim of administrative convenience").

A final possible criticism of judicial orders is that clever tabloids will find ways around them. For example, they might temporarily "hire" witnesses eager to sell their stories at very high wages, disguising payments for stories amidst other transactions. Alternatively, following Playboy's lead in the Jim Bakker case, they might make package deals which putatively pay witnesses only for pictures of the witness, claiming that the interview was uncompensated. See supra note 18. Judicial orders prohibiting witness payment would indeed be subject to this kind of manipulation and evasion, but no more so than the statute. See CAL. PENAL CODE $\$ 132.5$ (f) (prohibiting witnesses from receiving payment for one year after criminal act or, if prosecution is commenced, until final judgment is reached).

${ }^{181}$ See supra part II.C.

${ }^{182}$ See supra part I.B.1 (explaining the marketplace of ideas rationale). 
tions or exaggerations by a further exchange of ideas. If the story a witness tells the media is inconsistent with or more sensational than the story she tells in court or in other proceedings, that fact will be brought to the jury's attention. ${ }^{183}$ Likewise, if a witness's various accounts are fully consistent, and she displays other signs of trustworthiness, the jury will be made aware of that too. In short, permitting witnesses to sell their stories and to be cross-examined and even attacked for doing so will more likely promote the idea that truth will ultimately prevail than will a total ban on checkbook journalism.

The practice of checkbook journalism might initially appear to have little to do with another leading justification for the First Amendment: the self-governance rationale. On further reflection, however, important aspects of the self-governance rationale are at stake. This theory contends that a state can truly operate as a democracy only if it protects all political speech implicating matters of public concern, so that citizens can make informed choices about the ends the state will pursue and the means by which it will pursue them. ${ }^{184}$

Much of what witnesses sell to media organizations, despite the tabloid format in which it appears, is fundamentally political speech of great public concern. California's checkbook journalism law prohibits disclosure of information pertinent to a legitimate public desire to assess how well the judicial system works. ${ }^{185}$ Recent events have compounded the usual public concern for the criminal

${ }^{183}$ The Michael Jackson investigation provides a good illustration. Defense lawyers and prosecutors both recognized that witnesses' statements to the media about Jackson's conduct were inconsistent with and more sensational than their statements in depositions. See Weinstein, supra note 3, at A1.

${ }^{18}$ See supra part I.B.2 (explaining self-governance rationale).

${ }^{185}$ The Supreme Court has acknowledged the obvious fact that the public has a legitimate interest in monitoring the criminal justice system. See Florida Star v. B.J.F., 491 U.S. 524, 537 (1989) (noting that information about the commission and investigation of a violent crime is a "matter of paramount public import"); Landmark Communications, Inc. v. Virginia, 435 U.S. 829, 839 (1978) ("The operations of the courts and the judicial conduct of judges are matters of utmost public concern."); Mills v. Alabama, 384 U.S. 214, 218 (1966) (noting that the major purpose of the First Amendment is "to protect the free discussion of governmental affairs"). The public's great concern with issues of criminal justice is evident from numerous polls. See Victims' Rights Expanded, WASH. POST, Nov. 10, 1994, at C11 (documenting the overwhelming majority of voters who voted to expand victim's rights); David Zucchino, Political Preoccupation with Crime Isn't New, Dallas MORNING News, Dec. 8,1994 , at $43 \mathrm{~A}$ (discussing how today's extensive media coverage of violent crimes has created great public awareness of criminal justice). 
justice system, leaving it "poised for systemic criticism" and ready "to take political arms" in response to perceptions of unjust results. ${ }^{186}$ The public may be interested in hearing the kind of information that a witness in a criminal proceeding might sell, so that it can compare the evidence available in a case with the evidence adduced at trial and with the verdict ultimately produced by the system. In many instances, discrepancies between the evidence in the public arena and the evidence admitted at trial are attributable to legal rules such as the evidentiary rule against hearsay ${ }^{187}$ and the exclusionary rule, ${ }^{188}$ which often exclude relevant evidence. The scope and operation of the legal rules which should govern our system of justice, the self-governance theory would assert, is precisely the kind of political decision in which the people in a democracy ought to participate. ${ }^{189}$

Allegations of misconduct by public officials provide another example of how the statute could stifle important political speech. Suppose that a witness possesses information confirming suspected malfeasance on the part of a public official. The witness may likely

${ }^{186}$ Richard Parker, The Coming Legal Backlash, NEw REPublic, Mar. 20, 1995, at 21,22 (anticipating that an acquittal or hung jury in the O.J. Simpson trial will generate an intense political response to perceived failings of the criminal justice system). A new book by Professor George P. Fletcher shows that the public is becoming increasingly discontented with the workings of the criminal justice system and increasingly determined to overhaul it. See GEORGE P. FLETCHER, WITH JUSTICE FOR SOME (1.995).

${ }^{187}$ See FED. R. EVID. 801.

${ }^{188}$ See Mapp v. Ohio, 367 U.S. 643, 655 (1961) (mandating the application of the exclusionary rule in state courts). Reform of the exclusionary rule has been the subject of recent legislative debate in both the House of Representatives and the Senate. See Jeffrey Rosen, Search and Seizure, NEw REPUBLIC, Mar. 27, 1995, at 12, 13 (examining bills being debated in both houses and arguing that the Senate bill is "coherent in theory," but the House bill is "literally unintelligible"). The House version, expanding the scope of the "good faith" exception to the exclusionary rule, has already been passed. See Nancy Mathis, Warrantless Searches Receive House's Approval, Houston ChroN., Feb. 9, 1995, at A1.

${ }^{189}$ See supra part I.B.2 (discussing the self-governance rationale). It is virtually impossible to predict the impact on the public debate of the evidence unearthed and disseminated because of checkbook journalism. On one hand, publicity about inculpatory evidence that was excluded from trial could create political pressure to relax exclusionary evidentiary rules. On the other hand checkbook journalism could help illustrate, for example, the dangers inherent in hearsay testimony, bringing to light the rationality of our current rules in a way that the public would not otherwise appreciate. Whatever checkbook journalism's ultimate effect on public opinion, allowing it to continue, as opposed to banning it, will give the public an opportunity to formulate ideas about the legal system on the basis of a fuller spectrum of information and thus, according to the self-governance theory of the First Amendment, to make their decision in the most informed and democratic way. 
feel some duty to make the information known, but because of the inconvenience, loss of privacy, and political risk involved with dealing with the press and, specifically, condemning a public official, she may decide not to offer the information to the press. With a financial incentive, she may be inclined to bear the inconvenience and risk and to share the information. Under the California statute, however, our hypothetical witness would be unable to accept the financial incentive and therefore would remain silent, depriving the public of information of great concern.

After the conclusion of the investigation, the witness could again accept monetary inducements to report her knowledge to the media. ${ }^{190}$ In some instances, however, delay in the dissemination of speech results in the loss of the opportunity or desire to speak. ${ }^{191}$ That effective loss of the opportunity to disseminate the information could occur where, after a long investigation, law enforcement authorities do not uncover any evidence to corroborate the allegations of official misconduct and are forced to dismiss all charges against the official. With the investigation terminated, the witness would again be free to sell the story to the press, but after the lengthy, fruitless investigation, the public's concern over the charges would likely have dissipated, leaving the witness with no media outlet interested in paying for the information. The California statute's financial restrictions on the dissemination of certain types of speech would have permanently deprived the public of information of public concern involving the integrity of their elected officials, in derogation of the self-governance rationale underlying the First Amendment.

190 Under the California statute, the individual is precluded from accepting any monetary compensation to report her knowledge for one year, unless either no prosecution is commenced or, if a prosecution is commenced, until a final judgment is reached. See CAL. PENAL CODE $\S 132.5(\mathrm{~d})$.

${ }^{191}$ The Court has noted, "[d]iscussion that follows the termination of a case may be inadequate." Pennekamp v. Florida, 328 U.S. 331, 346 (1946); see also Shuttlesworth v. City of Birmingham, 394 U.S. 147, 163 (1969) (Harlan, J., concurring) ("W] $[W$ hen an event occurs, it is often necessary to have one's voice heard promptly, if it is to be considered at all."); Carrol v. President of Princess Anne, 393 U.S. 175, 182 (1968) ("The present case involves . . . 'political' speech in which the element of timeliness may be important."); ALEXANDER M. BICKEL, THE MORALITY OF CONSENT 61 (1975) (" $[\mathrm{I}] \mathrm{t}$ is the hypothesis of the First Amendment that injury is inflicted on our society when we stifle the immediacy of speech."); Vincent Blasi, Toward a Theory of Prior Restraint: The Central Linkage, 66 MINN. L. REV. 11, 33 (1981) ("Although one can never be certain about the impact of delay, it is possible that on some occasions persons who lose control over the timing of their utterances thereby lose their desire to speak."). 
Alternatively, suppose authorities decided to bring charges against the official. Suppose further that the same witness possesses several pieces of second-hand circumstantial evidence incriminating the official, but, again, without financial incentive, concerns of convenience, privacy, and political retaliation make her hesitant to speak to the press. Even if she is called as a witness, most of her testimony would be excluded as hearsay from both the trial and, consequently, from the trial's press coverage, effectively eliminating her speech from the public debate. The loss of this witness's allegations would be a loss of fundamental political speech. Although the hearsay allegations would have been properly excluded from the criminal trial, many citizens would find the allegations relevant to their decisions as voters, and the voters have a right to withhold a vote from a candidate, even if their concerns cannot be confirmed beyond a reasonable doubt. The statute would have effectively removed considerations of possible misconduct from the public debate, depriving the electorate of what it would consider valuable information. ${ }^{192}$ By proscribing the sale of this kind of information, the checkbook journalism law eliminates from the public sphere more than just gossip and scuttlebutt. It frustrates what the Supreme Court has described as the primary purpose of the First Amendment: "an unfettered interchange of ideas for the bringing about of political and social changes." 193

\section{B. Judicial Orders}

Because they would burden expression much less frequently than the statute, judicial orders are more compatible with both the marketplace of ideas and the self-governance theories of the First Amendment. Judicial orders will prohibit witnesses from selling

192 The checking rationale, like the self-governance rationale, is a theory of the First Amendment based on the concept of representative government. It differs from the self-governance theory in that it believes "the role of the ordinary citizen is not so much to contribute on a continuing basis to the formation of public policy as to retain a veto power to be employed when the decisions of officials pass certain bounds." Blasi, supra note 65 , at 542 . Blasi maintains that "the abuse of official power is an especially serious evil" and that the check on public officials "must come from the power of public opinion, which in turn rests on the power of the populace to retire officials at the polls, to withdraw the minimal cooperation required for effective governance, and ultimately to make a revolution." Id. at 539. It is clear from these quotations that the statute is at odds with the basic principles of the checking rationale of the First Amendment. See id. at 527-42.

${ }^{193}$ New York Times v. Sullivan, 376 U.S. 254, 269 (1964). 
information relating to criminal proceedings only when a court has found that other measures will not adequately prevent extensive consumption by the public of prejudicial information, whereas the statute prohibits witnesses from selling this kind of information even when there is little or no threat of prejudicial publicity. Judicial orders will thus allow more speech to reach and be tested in the marketplace of ideas than will the statute. They will also facilitate the democratic process better than the statute by permitting more speech on public issues to come to people's attention.

\section{CONCLUSION}

The First Amendment and the Sixth Amendment each embody fundamental constitutional guarantees, which can come into direct conflict when a criminal trial is attended by sensationalized and prejudicial publicity. Because the Constitution provides no insight into whether either of these rights can ever trump the other, the Supreme Court has long sought to balance them "without essentially abrogating one right or the other." 194 The California statute, by failing to achieve a close nexus between the end of securing fair trials and the means by which it pursues this goal, abrogates free speech rights in many instances in which doing so is unnecessary. The use of alternatives such as cross-examination, which protect the integrity of the trial process without suppressing speech, combined with exceptional measures such as judicial orders, which can be employed in especially difficult cases and calibrated to restrict no more speech than necessary, will ensure that more information of public concern will enter the marketplace of ideas, leading to more informed and educated decision-making by the electorate.

${ }^{19}$ Nebraska Press Ass'n v. Stuart, 427 U.S. 539, 612 (1976) (Brennan, J., concurring). 
